\title{
التحليل التمييزي للمشاركة السياسية للشباب الريفي بمحافظة المنوفية
}

\section{فؤاد عبد اللطيف سلامة ، فرحات عبد السيد محمد ، خالد عبد الفتاح قنيبر، \\ محمد عبدالله يونس}

قسم الإشاد الزراعي والمجتمع الريفي - كلية الزراعة - جامعة المنوفية

Received: Nov. 14, 2017

Accepted: Dec. 2 , 2017

الملخص

استهافت هذه الدراسة وصف وتحليل المشاركة السياسية للشباب الريفي، ولتحقيق أهداف الدراسة تم اختيار عينة عشوائية

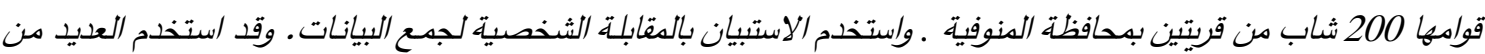
الأساليب الإحصائية لتحليل البيانات واستجلاء نتائج الدراسة منها أساليب الإحصاء الوصفي، وكذلك التحليل التمييزي للمقارنة بين مجموعتي الدشاركين وغير الهشاركين سياسيا بالنسبة لمتغيرات التصييز الدستخذمة .

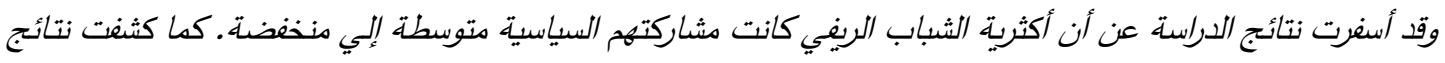

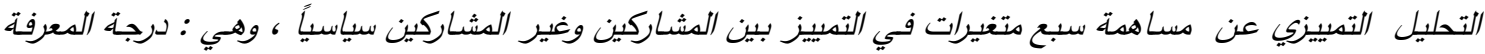
السياسية للشباب، مستوى تعليم المبحوث، متابعة المبحوث للأخبار السياسية بوسائل الإعلام والإنترنت، التنشئة الاجتماعية والسياسية للمبحوث، شعور المبحوث بالرضا عن القرية، مشاركة المبحوث في الدنظمات الاجتماعية، ومستوى تعليم أسرة

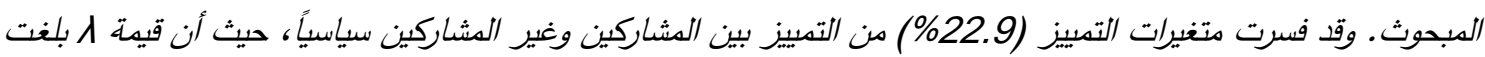
0.770. كما أوضحت النتائج أن نسبة التصنيف الصحيح للمشاركين وغير المشاركين قد بلغت 72\% وفئًاً لمتغيرات التمييز

التغيرات لم تعد ترتبط بأشخاص بقدر ارتباطها بالدور الذى

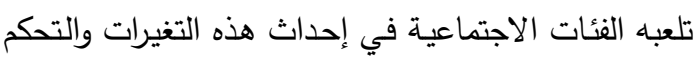
في انعكاسـاتها، ولقـــ شــل الـدور الـذى تلعبـه الفئسات الاجتماعية في إحداث وتوجيه تلك التغيرات حيزاً كبيراً من

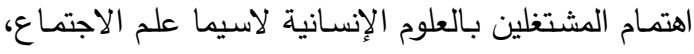

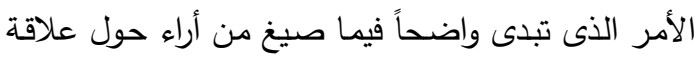

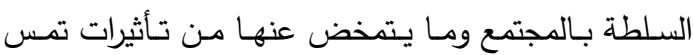

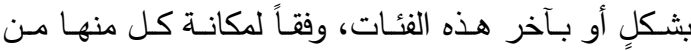

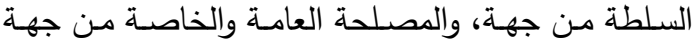

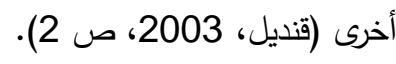

وتثـير إينـاس ميخائيـل (1999، ص39) إلـى أن

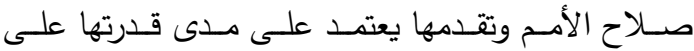
الاستفادة الكاملة من الإمكانيات والموارد المادية والبشرية

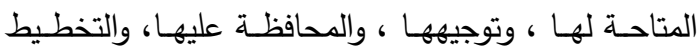

\section{المقدمة والمشكلة البحثية}

تأتي أهمية المشاركة السياسية في الوقت الحاضر من

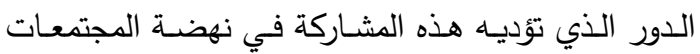
وتطورها باعتبارهـا شرطاً أساسياً لتحقيق التتميـة الفعليـة، كما ترتبط المشاركة السياسية بتامي السلوك الحضاري في المجتمعات التي تتجهـ نحو الديمقراطية، حيث أصبحت

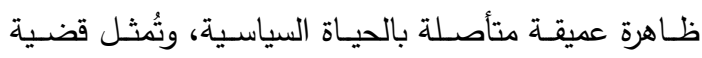

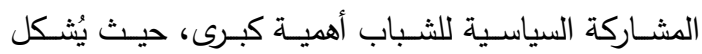

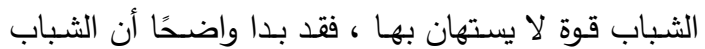
المصــري يلعـب دورًا فــاعلاً فـي الأحــاث السياســية والاقتصادية خاصـة بعد ثورة 25 يناير 2011 ، وتجلت قدرته في الإطاحة بنخب الحكم.

ويشه العالم في الوقت الراهن تغيرات سريعة ومتلاحقة

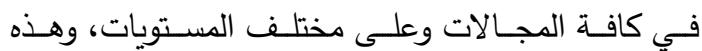




\section{F.S. Salama, et al.,}

أساسي لأي تطور ديمقراطي حقيقي ( عبد الحميد ، غير

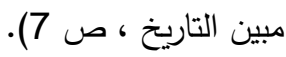

ويمثل الثباب الريفي شريحة كبيرة من تعداد السكان وقـوة العمـل في مصـر ، وأن قضـية المشـاركة السياسـية

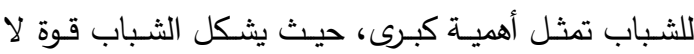
يستهان بها، وأن الاهتمام بعملية التتشئة السياسية لهؤلاء

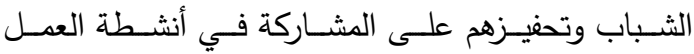

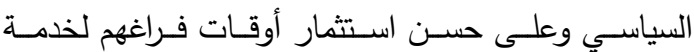
مجتمعاتهم، كل ذلك يسهم وبشكل كبير في نجاح برامج

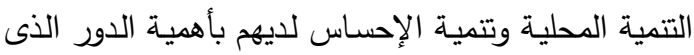

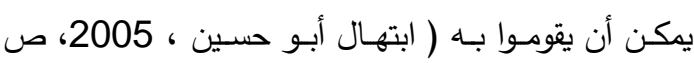

.2102

ويـــكر العزبــي ( 1988، ص 24ش) أن إبعـاد

السكان الريفيين عن الششاركة خلق لديهم شعور بالعز

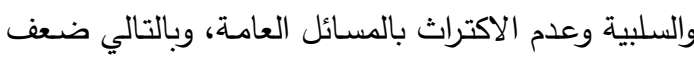
مشاركتهم، على الرغم من أن قضية المشاركة السياسية للسكان الريفيين تمثل أهمية كبرى ، حيث يُشكل السكان

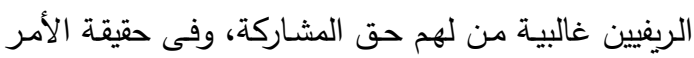

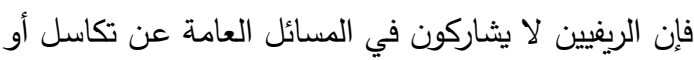

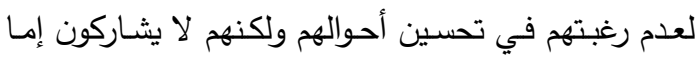
لمنعهم من المشاركة، أو عدم قدرتهم على المشاركة، أو لإحساسهم بأن مشاركتهم لن تغير أو تؤثر في الواقع كثيراً. وعلى الرغم من الأهمية الكبرى التي تمثلها فئة الثباب

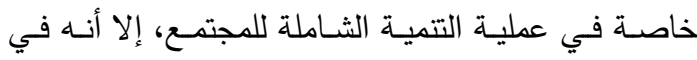

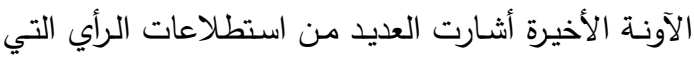

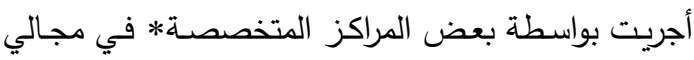

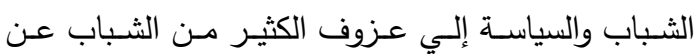

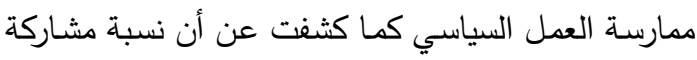

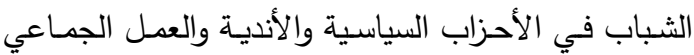
والتطــوعي مجتمعـة لا تتجــاوز نحـو 2.5\% ، كنتيجـة

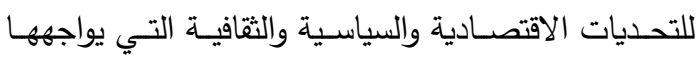

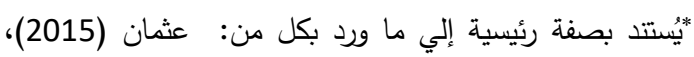
مجدي (2015)، وحسنين (2015).
لإصلاحها وتتميتها ورعايتها على أسس صحيحة وسليمة ،

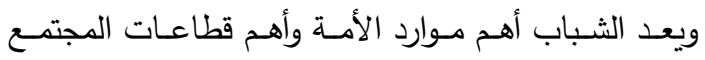
وفئاته، فبدونهم لا يمكن اكتشاف الموارد المادية ولا يمكن

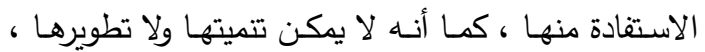

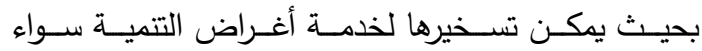
الاجتماعية أو الاقتصادية أو السياسية.

كما يُبرز عضييات (2009) أهمية ودور الثباب في

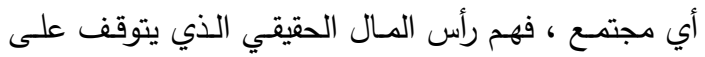
طريقة استثماره والتعامل معـه حاضر المجتمع ومستتبله،

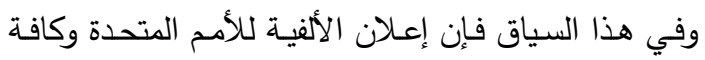

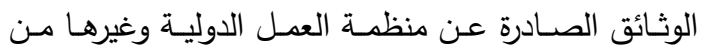

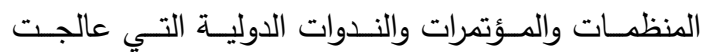
موضوع الثباب، تؤكد على أن الثباب يشكلون مصدر قوة وليسوا عبئًا على المجتمع والدولة. وتُعتبر المشـاركة بكافـة أشـكالها ومجالاتها حق مـن الحقوق الأساسية للإنسـان كمـا ورد في الميثاق العـالمي

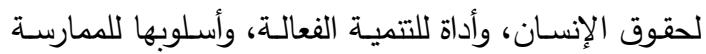

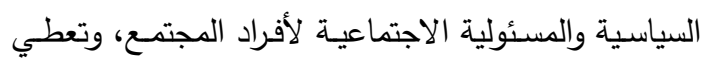

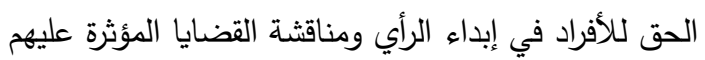

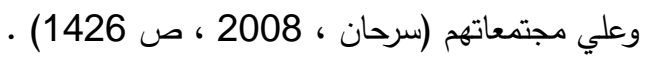
فالمشاركة السياسية تدعم الديمقراطية مما يسهم في

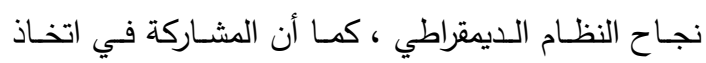
القرارات وتقرير السياسات تحقق رضاء المواطنين عن ما يقدم اليهم من خدمات، مـع تتميـة إحساسهم بذاتهم مها يخلق حالة عامة من الثعور بالرضا (الجوهري ، 1985،

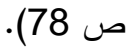

ويأتي الاهتمام بقضية المشاركة نتيجة للقناعة الراسخة بأن أي تغيير منشود لأحوال الناس والانتقال بهم خطوات

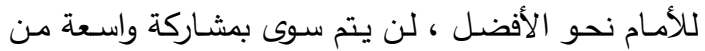

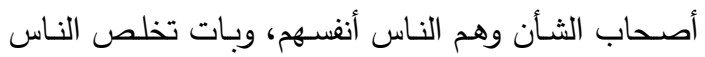
مـن السـلبية ضـرورة لا محيص عنهـا، ومـن هنـا جـاء

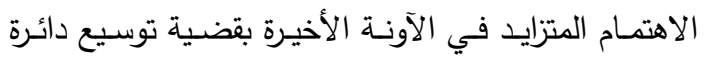

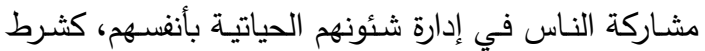


1- ما مستوى المشاركة السياسية للشباب الريفي ؟

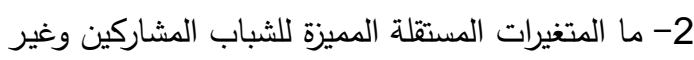

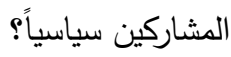

\section{أهداف الدراسة}

تسعى هذه الدراسة إلى تحقيق الأهداف التالية: 1. التعرف على مستوى المشاركة السياسية. 2- التمييز بين الثباب المشاركين وغير المشاركين سياسياً بعينة الدراسة.

\section{الإطار النظري والاستعراض المرجعي}

اولاً: مفهـوم المشــاركة السياسـية: يمكـن تصـنيف

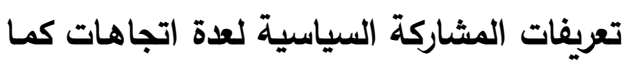
يلي: الاتجاه الأول: يقوم على مسـاهمة الأفراد في أي جانب

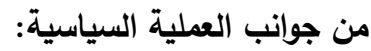

يتفاوت تعريف المشاركة السياسية في الدراسات والأدبيات السياسية من دراسة إلى أخرى، ما بين التتاول

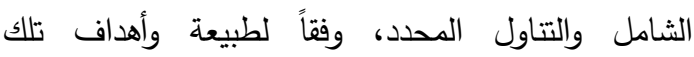
الدراسات، والأساس الذي انطلقت منه، فالمشاركة في ولفي أضيق معانيها تعني: حق المواطن في أن يقوم بمراقبة

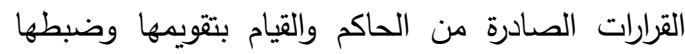

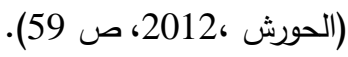

فيعرفهـا الجـوهري (1985، ص 23) بأنها "العمليـة

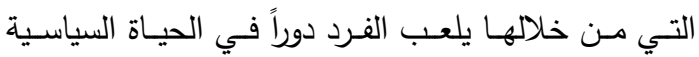

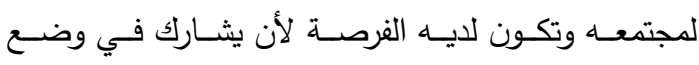

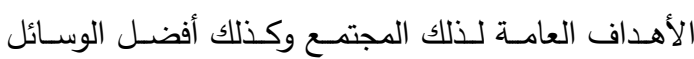

$$
\text { لتحقيق وإنجاز هذه الأهداف". }
$$

كما يعرفها رحال وآخرون (2014 ، ص 119) بأنها

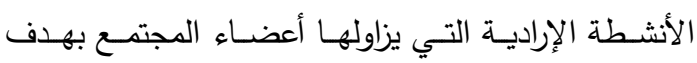
اختيار حكامهم وممثليهم ، والمساهمة في صنع السياسات

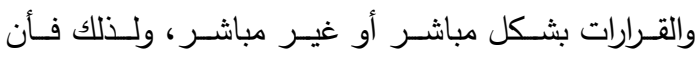
المشاركة السياسية ليست مجرد تصويت في فترة انتخابات معينة ، بل توجها عاما واهتماما واضحا من قبل المواطنين
هؤلاء الثباب والمؤثرة عليهم بشكل سلبي، مما دفع الكثير

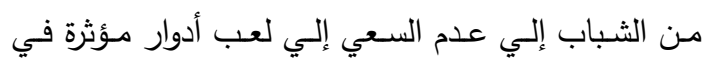

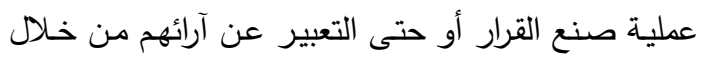
المشاركة بالتتظيمات السياسية أو الأهلية. ومـن هذا المنطلق تتضـح أهميـة المشـاركة السياسية

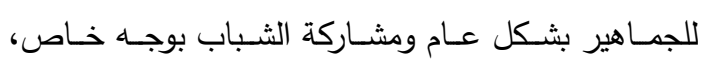
فالثـباب بمـا لديـه مـن إمكانيـات وطاقـات يعد مـن أهم

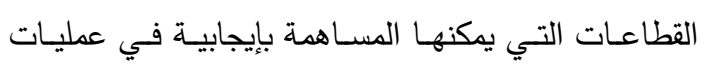

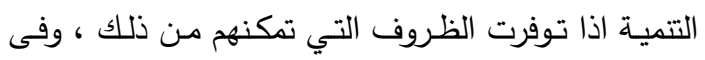

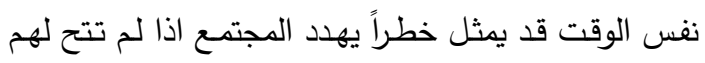

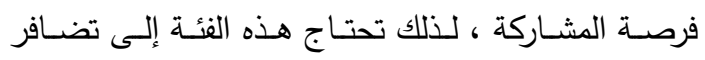

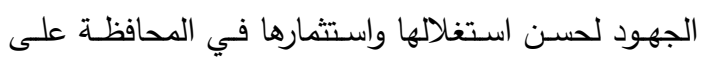

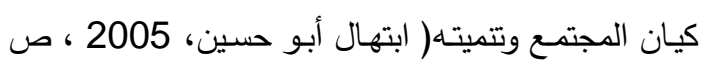
ص 2101-2102). ومن ثم يتضح أن غياب المشاركة السياسية الفعالة من

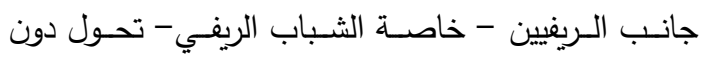

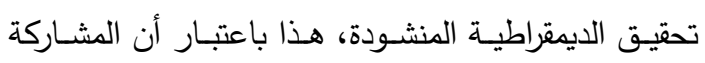

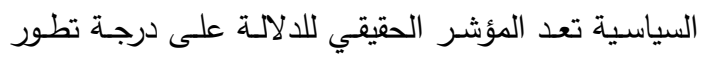
النظام السياسي للمجتمع ، وحتى يمكن الاستفادة الكاملة

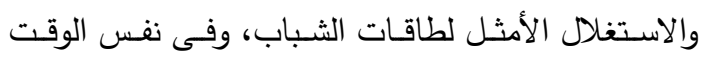

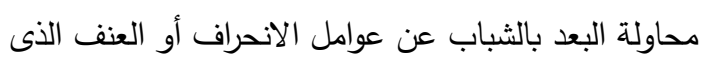
يهدد تماسك المجتمع ، فان ذلك يتطلب المزيد من العناية

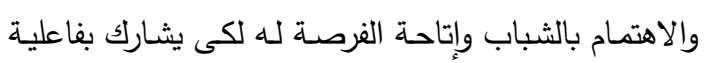

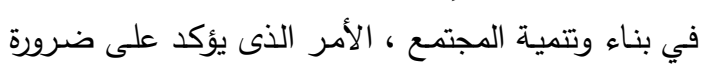

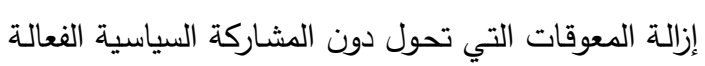

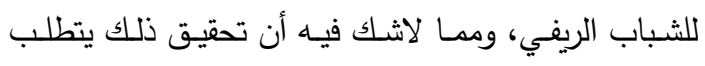
بداية توافر المعارف العلمية التي تساعد على فهم وتفسير لإنيل السلوك السياسي للشباب الريفي وتحديد العوامل المؤثرة عليه. لذا أجريت هذه الدراسة للتعرف على كل من: مستوى

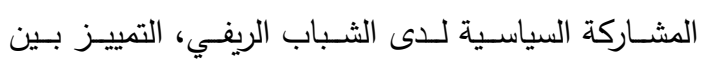
الشباب المشاركين وغير المشاركين سياسياً. ومن ثم فإن الدراسة الحالية تسعى للإجابة على التساؤلات الآتية: 


\section{F.S. Salama, et al.,}

كالتصــويت فـي الانتخابـات والمشــاركة فــي الأحـزاب

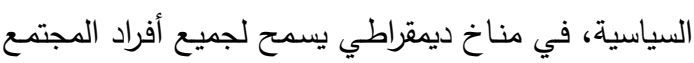
بممارسة تلك الأنشطة (النبي، 2013، ص 183).

\section{الاتجاه الثاني: يقوم على العلاقة بين المشاركة السياسية}

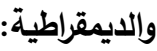

تثــير حفيظـــة شــقير (2004، ص 16) إلــى أن

المشاركة السياسية تُمثل أرقى تعبير للديمقراطية لأنها تقوم على مساهمة المواطنين والمواطنات في قضايا الددينة أو الحي أو المؤسسة، وتتدرج المشاركة السياسية في إطـار التعبير السياسي الثعبي وتسيير الثشأن السياسي من قبل الثل كلّ أطراف المجتمع وكلّ النساء والرجال.

كمـا أنها لا تعنـي بالضـرورة مشـاركة الفـرد بالعمليـة السياسية بمفهومها المحدد الضيق الخاص بسياسة الدولة

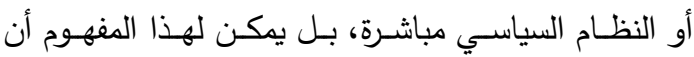
يختص بجانب واحد من جوانب المشاركة السياسية مثل الإصلاح الاجتماعي أو الإصلاح الديمقراطي وحتى العمل

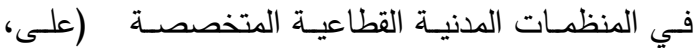

$$
\text { 2009، ص 28). }
$$

ويتفق كثير من علماء ودارسي علم الاجتماع وعلم

السياسة ، علي أن المشاركة السياسية هي العصب الحيوي

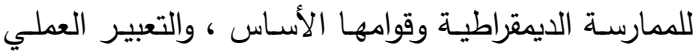

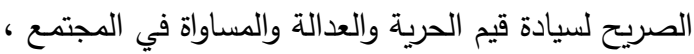

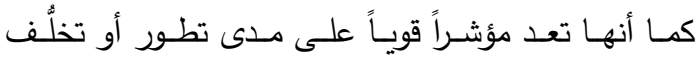
المجتمع السياسي، وما يعنيه ذلك من ارتباط وثيق بينها وبين جهود التتمية بصفة عامـة ، والتتميـة السياسية على التى وجه التحديد ( الطبيب ،2007، ص ص 86 -85). كما تُعرف بأنها أساس الديمقراطية والتعبير الواضح عن مبدأ سيادة الشعب ، وتقتضى الشـاركة وجود أفراد يتوافر لديهم شعور بالانتماء ، وهى أرقى تعبير عن مفهوم

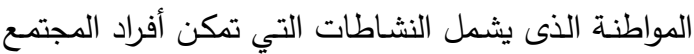
من ممارسة السلطة السياسية (متولى ، 2012، ص 81). الاتجــاه الثالــث: يقـوم علـــ الفـرض مـن المشــاركة

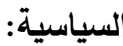

بقضـية القـرار السياسـي ونتائجسهـه ، وذلـكـ مـن خـلال

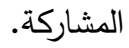

كما تُعرف بأنها المشـاركة في صنع القرار السياسي والإداري والتحكم في الموارد على كافة المستويات، فهي سلوك مباشر أو غير مباشر يلعب بمقتضاه الفرد دوراً في

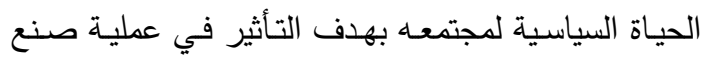
القرار ، وهي من آليات الديمقراطية في المجتمع التي تتيح

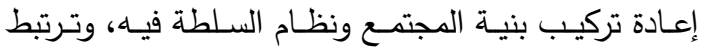
بالاهتمـام بالثـأن العـام وبمشـاركة المواطنين في إنجازه، وبالتالي فهي تعبير للمواطنة ويجب أن تقوم على الحقوق

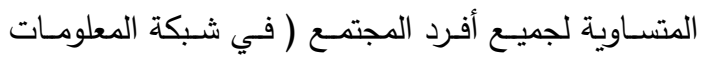
الدولية : http://www.rdflwomen.org.). ويمكـن تعريـف المشـاركة السياسـية بأنهـا مجمـوع النشـاطات الجماعيـة، التي يقوم بها المحكومـون، وتكون

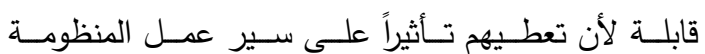

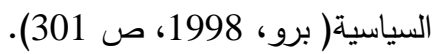

المشـاركة السياسية عمليـة يقوم من خلالها الفرد أو

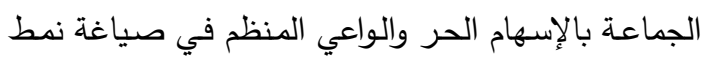
الحياة السياسية للمجتمع، وتتم عملية المشاركة السياسية

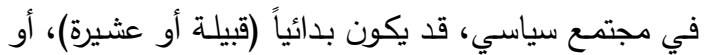
عصرياً (الدول والمنظمات الدولية) (تاج الدين، غير مبين

$$
\text { التاريخ، ص 9- (10 } 10 \text { ). }
$$

وتُشكل المشـاركة السياسية الفعـل الإرادي للشـص

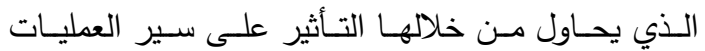

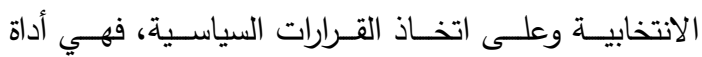
للاستقرار السياسي، بحيث يمكن طرح بعض الإنكالات المتعلقة بالمشاركة السياسية مثل حق الانتخاب، التمثيل، التأثير على الخطوط الكبرى لسياسة ما بحيث تمثل هذه العمليات الثعب في نشاطات تدخل ضمن دمقرطة الحياة اليومية للمواطنين (لمين، 2007، ص 237).

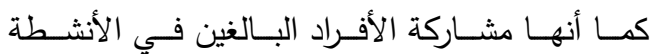
السياسية، بشكل تطوعي واختياري سواء أكانت مشاركة سـلبية كالإضــراب والاعتصـامات أو مشــــاركة إيجابيــة 
البداية، وثــة من يؤكد أنهم يقعون في الثريحة العمريـة

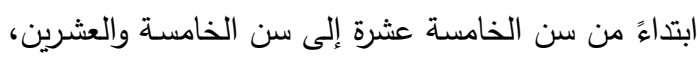

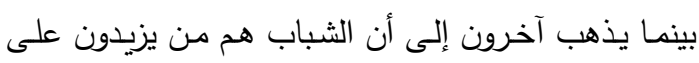

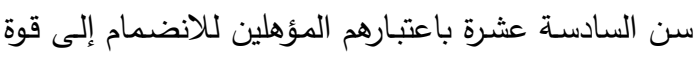

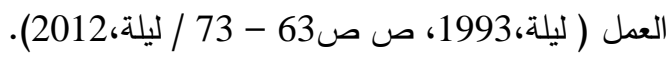
وقد اختلف المتخصصين بالمؤسسات والهيئات الدولية

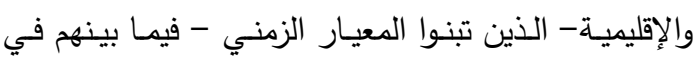

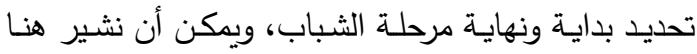

$$
\begin{aligned}
& \text { إلى أربعة آراء بارزة في هذا السياق: } \\
& \text { الرأي الأول: من 1313 إلى30 سنة ارئة } \\
& \text { الرأي الثاني: من 15 إلى 130 سنة }
\end{aligned}
$$

الرأي الثالث: من 15إلى25 سنة وهذا الرأي يمثل حصيلة

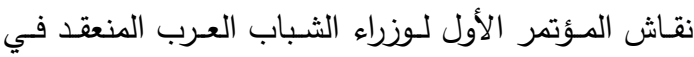
القاهرة عام 1969. الرأي الرابع: 18إلى 30سنة (في شبكة المعلومات الدولية: http://himayashabab.blogspot.com.eg/2011/0 .( 5/blog-post_18.html وليس هناك اتفاق على المستوى الدولي بشأن تحديد

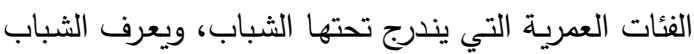
بأنهم الأشخاص الذين يندرجون تحت الفئة العمرية من 18

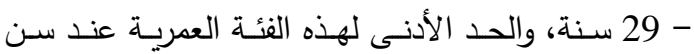
الثامنة عشر، ويتفق بذلك مع القانون المصري الذي يرى

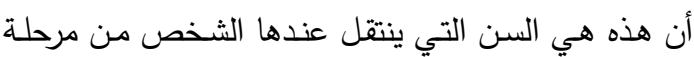

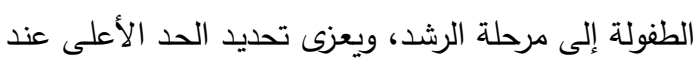

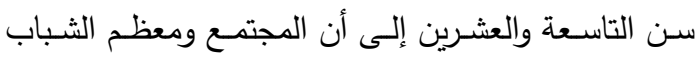

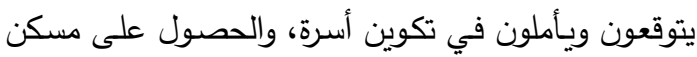

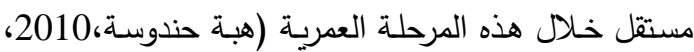

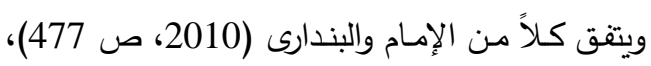

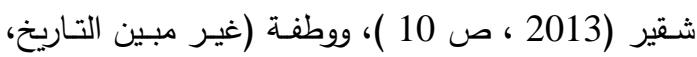

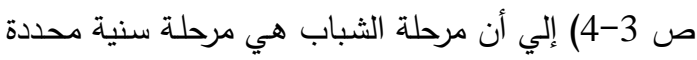

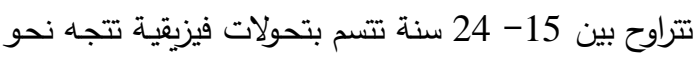
النضج وتتحول فيها الطاقة الى قوة عمل في حالة توجيه

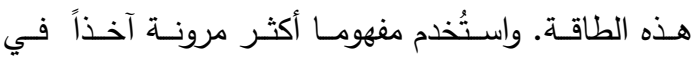

ويتفـق كـلاً مـن علـى (2008 ، ص27)، وسوسـن شاهين (2010) على أن مفهوم المشاركة السياسية: يقوم

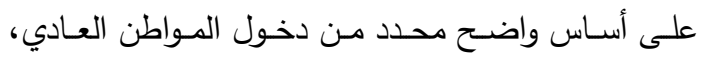
بمض اختياره وبكامل إرادته في نشاط جماعي اجتماعي

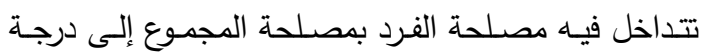

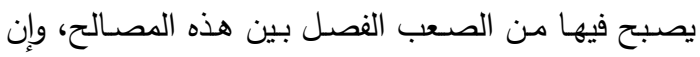
تراوحت حدتها حسب الوضع أو المجتمع المعين.

ويُعرف قاموس الخدمة الاجتماعية المشاركة السياسية

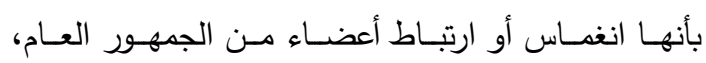

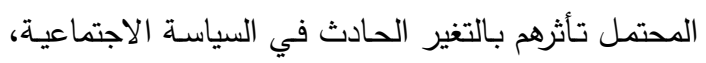

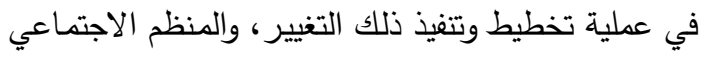
المـاهر يحاول دائما تسهيل مشاركة المواطنين في جهود

$$
\text { التغيير (على، 2009، ص بـ 726). }
$$

وتعرف بأنها عملية ذات طابع اجتماعي سياسي تمثل محور عمل النظام السياسي الديمقراطي، حيث تيتل الفرات الفرد

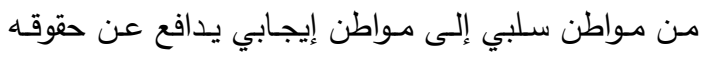
ويعـرف واجباتـهـ السياسـية والاجتماعيـة تجــاه قضـــاياه

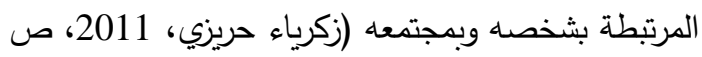

ثانياً: مفهوم الثباب: لم يتفق الباحثون والمختصـون

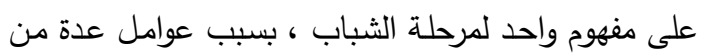
بينها اختلاف مشارب الباحثين وتخصصاتهم ، فمنهم من

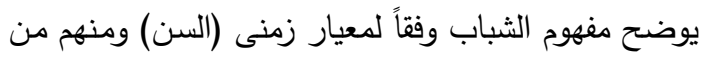

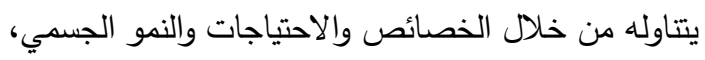

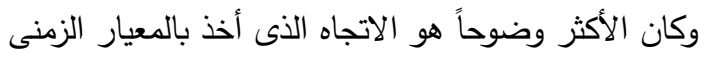

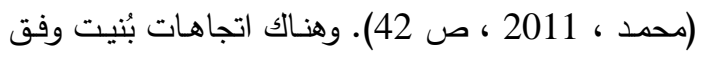

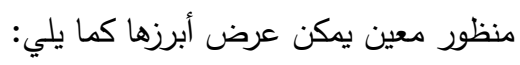
1- الاتجاه الديمغرافي: يُعتبر علماء السكان هم أول من

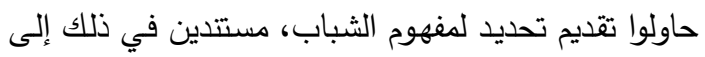

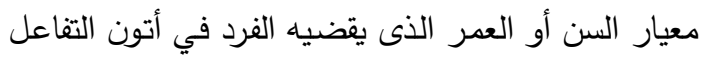

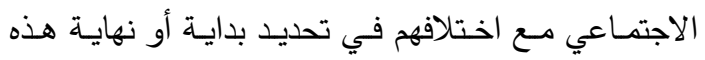
المرحلة، حيث يؤكد بعضهم على أن الثباب من هم دون

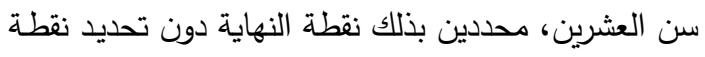


الهروب من الحياة ، وهذه بدايات مرحلـة الثيخوخة

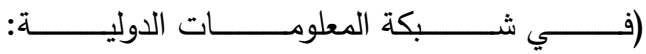
http://himayashabab.blogspot.com.eg/201 .(1/05/blog-post_18.html كما أن من المرادفات التي تقابل مفهوم الشباب في

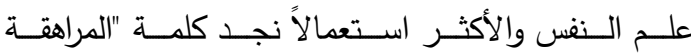
Adolescence Adolescerre والجنسـي والعقلـي والانفعـالي" وهـي كلمسة لا يقصــ بهـا

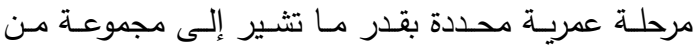
الخصائص النفسية والجسمية التي تكون في حالة نثاط وقوة وفي حالة من التهور والاندفاع أيضاً سواءً بالنسبة النية للفتى أو الفتاة (ملحم ،2004 ، ص صن 341).

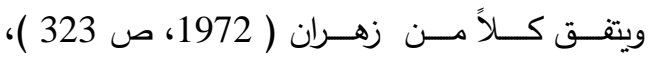

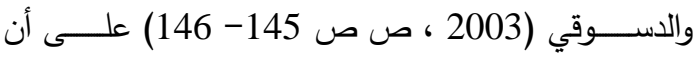

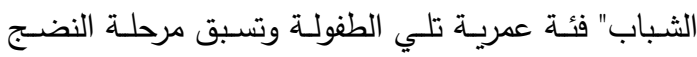
والرشـــ وتقـع أعمـارهم بـين (11- 21 ) ســنة ". كمــا أن مرحلة الثباب تبدأ من مرحلة المراهقة المتأخرة وتمتد حتى ولى

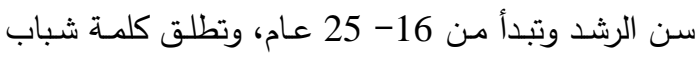

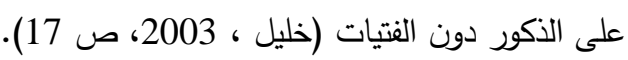
ويشير واطسون وليندجرين (2004، ص ص 575 577) إلى أن المراهقة هي فترة النمو التي تفصل الطفولة

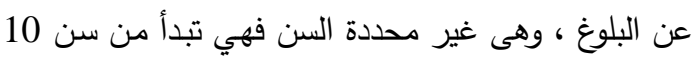

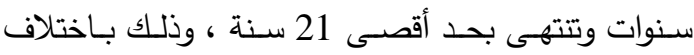
المجتمعات التي يعيش فيها المراهق ، ويحدث للفرد فيها عدة تغيرات فسيولوجية كزيادة الطول والوزن . 4- الاتجـاه السوسيولوجي: لعلماء الاجتماع تشخيصهم

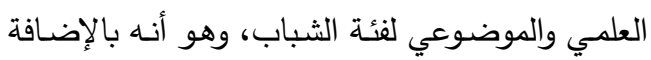
إلى التحديد العمري فإن فترة الشباب تبدأ حينما يحاول

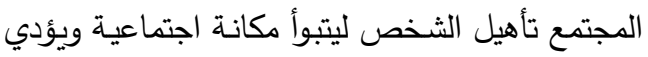

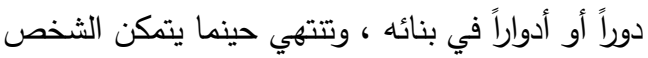

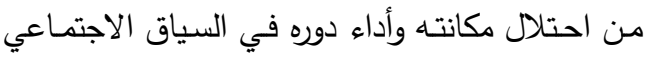

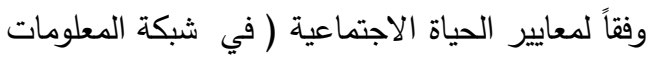

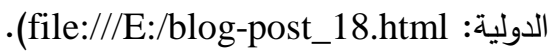

الاعتبار الطبيعة المتباينة للسكان الثباب واختلاف تعريف

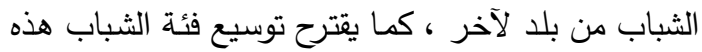
لتشمل الثابات والثبان الذين تتراوح أعمارهم ما بين ( 25 -30عاماً) وحتى تخطي ذلك وصولاً إلى35 عاماً، مستنداً إلى السياسـة الإقليميـة والوطنيـة المتعلقة بالشباب(برنامج الأمم المتحدة الإنمائي، 2014، ص الفئة 9). وفي هذا الثأن يمكن تعريف الثباب وفقاً لها ورد في الدستور المصري (2014) فوفقاً للمـادة (80) يعد طفلاً كل من لم يبلغ سن الثامنة عشر من عمره ، وتنتهي فترة

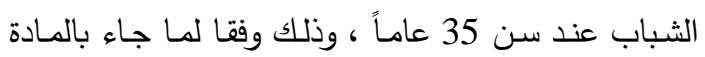

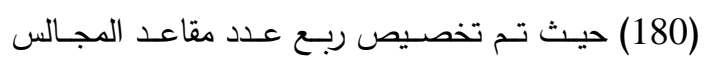
المحلية للشباب حتي سن الخامسـة والثلاثين عامـاً، كمـا أشارت المـادة (2) من قانون مجلس النواب إلي أن سن

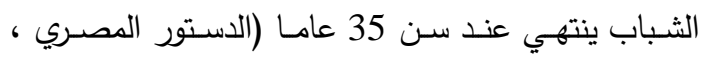

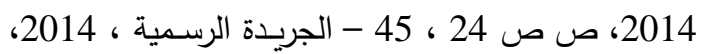
ص 38) ، وهو ما أخذت به الدراسة. 2- الاتجاه الشرعي القانوني: رغم أن هذا الاتجاه يتعامل

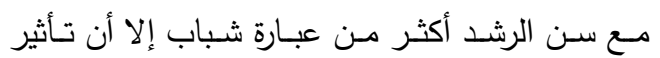

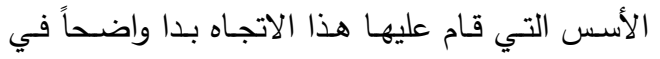
تحديد هذه الفئة العمرية ووفق هذا المنظور فإن مرحلة الشباب تبدأ عند الحد الزمني الذي يصبح فيه الفرد في

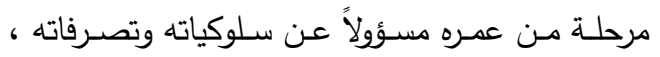
ويتحمل تبعاتها من دون وصاية أو ولاية عليه ، وهذا

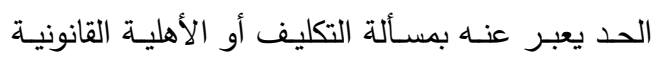

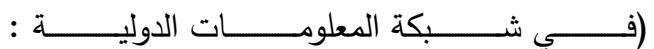
http://himayashabab.blogspot.com.eg/201 .( 1/05/blog-post_18.html

3- الاتجـاه السيكولوجي : يرى أنصـار هذا الاتجـاه أن الثباب ليس مرحلة عمريـة تتحدد بسن معينة، وإنما لياه حالة نفسية لا علاقة لها بالعمر الزمني، فالفرد يعد

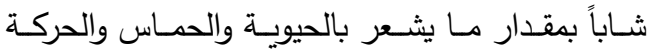

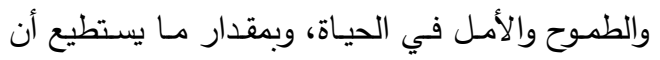

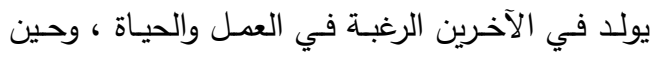

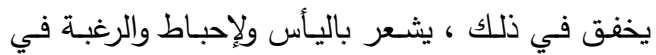


إحصـائية في تحليل البيانـات مـن بينهـا النسب المئويـة،

والتوزيـع التكـراري، وبعض مؤشـرات التحليـل الإحصـائي

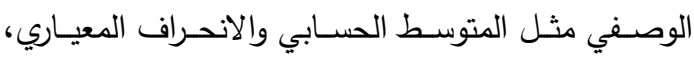
والمدى، كما استخدمت الدرجات التائية (T-Scores) في معسايرة وتكوين بعض المتغيـرات المركبـة، واسـتخدم Discriminant analysis أسلوب التحليل التمييزي technique مجمـوعتي الدراسـة المشـاركين وغير المشـاركين سياسياً. واعتمد في تحليل بيانـات الدراسـة على برنـامج التحليل SPSS)Statistical Package for Social الإحصائي

.(Sciences

\section{قياس المتغيرات البحثية}

1. عمر المبحوث: يُعبر عن عدد السنوات الميلادية التي

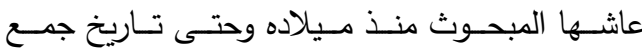

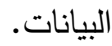

2ـــــــوى تعليم المبحـوث: يُعبـر عـن عـدد السـنوات

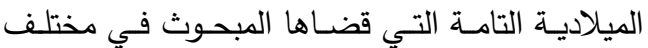
مراحل التعليم الرسمي. - (التهي.

3ـ الــخل الثـهـري للمبحــوث: تـم قياسـهـ بجمـع إجمـالي المبالغ النقدية التي يتحصل عليها المبحوث من عمله

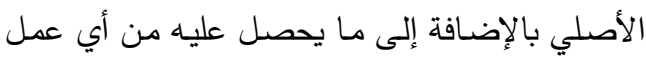
إضافي يقوم به خلال الثهر مقدراً بالجنية المصري.

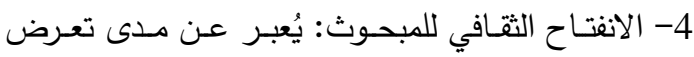
المبحوث لوسائل الإعلام المختلفة (المسموعة والمرئية والمقـروءة) والتـي يسـتقى منهـا المبحـوث معلوماتــهـ السياسية، وهي مشاهدة التليفزيون، الاستماع للراديو،

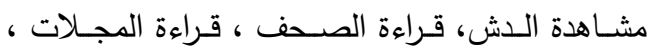
قـراءة الكتب ، وحضــور الندوات والمـؤتمرات ، وقدـ

* T-Score $=10 Z+50$,

$\mathrm{Z}$ (Standard Score) $=\mathrm{X}-\mathrm{M} / \mathrm{S}$ :

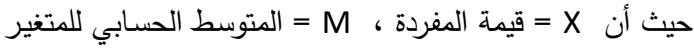
المـراد معـايرة قيمـة، S S الانحـراف المعيـاري للمتغيـر المـراد معايرة قيمة (علام ، 1985 ، ص ص ص 197-214).
ويتفق ذلك مـع مـا ذكره حجـازي ( 1985، ص ص 27-28 ) معتبراً أنـه خـال المرحلة العمريـة مـا بين سن

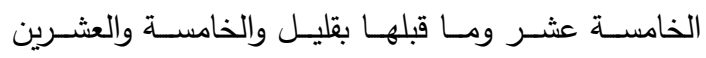
وماحولها، تحدث تحـولات هامـة في حيـاة الفرد الثـابة، "فعندها يترك التعليم بعد استكماله - عادة - ويلتحق بعمل دائم ويتزوج، أو يسعى إلى تحقيق ذلك على الأقل، فهو

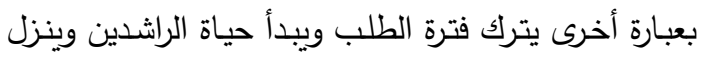
إلى معترك الحياة ويرتبط بعدد من المؤسسات التي يتعامل مها الراشدون، ويتغير تبعاً لذلك تصسوره لذاته وللآخرين

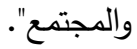
كما يُعرف حجازي (2006، ص 203 ) الشباب بأنهم

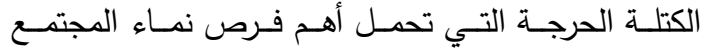
وصناعة مستقبله، كما أنهم في الآن عينه يشكلون التحدي الكبير في عملية إدماجهم في مسارات الحياة الاجتماعية والوطنية والإنتاجية النشطة والمشاركة، فهم يشكلون العبء الذي تضيق به السلطات ذرعاً.

\section{الإجراءات البحثية}

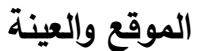

أُجريت الدراسة في قريتين بمحافظة المنوفية هما: قرية كفور الرمل التابعة للدائرة الانتخابية الثالثة (قويسنا وبركة

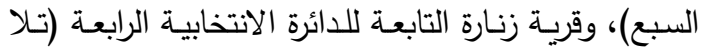
والثـهاء)، ولتحقيق أهداف الدراسـة تطلب اختيـار عينـة عشوائية بسيطة قوامها 200مبحوث، بواقع 100 مبحوث

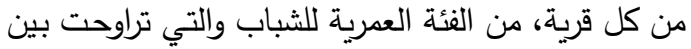
(20- 35 سنة) من واقع البيانات الإحصائية لعام 2016

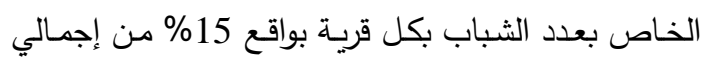

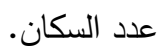

\section{جمع وتحليل بيانات الدراسة} استخدم الاستبيان بالمقابلـة الشخصية لجهـع بيانـات الدراسة، وذلك بعد اختبار صلاحية استمارة الاستبيان في لاني تحقيق أهداف الدراسـة. واستغرقت عمليـة جمـع البيانـات نحو خمسـة أشهـر حيث بدأت في أغسطس وانتهت في

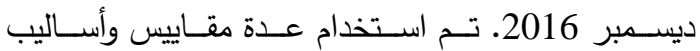


= 3 درجات ، كل 6 شهور = 2 درجـة ، سنويا =

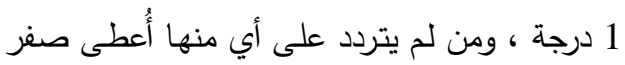
درجة ، واستُخدم مجموع الدرجات التي حصل عليها المبحوث كمؤشر رقمي لقياس هذا المتغير.

8ـ التتشـئة الاجتماعيـة والسياسية للمبحوث: يقصــ بهـا

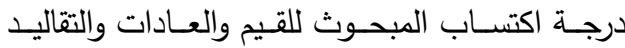
والأفكار والاهتمامات الرئيسية للأنساق الاجتماعية، من خـلال المواقف والخبرات المتعددة التي يتعامل فيها مع الآخرين - سواء على نحو مباشر أو غير

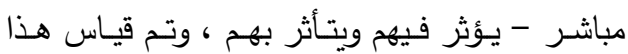
المتغيـر بسؤال المبحـوث عن رأيسه في 22 عبـارة اتجاهية جميعها سلبية الاتجاه ومتضمناتها (الاهتمام بالسياسة من قبل المدرسة والأسرة والأصدقاء، التربية الاجتماعية للأفراد لقبول عمل المرأة وتعليمها وغيرها

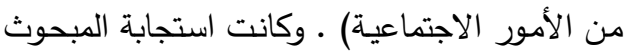
عن كل عبارة بأحد الإجابات التالية: موافق ، محايد،

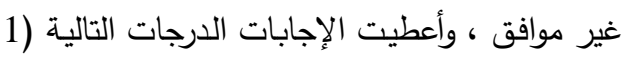

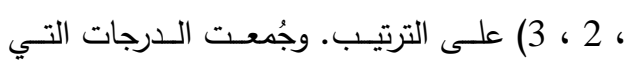
حصل عليها واستُخدمت كمؤشر رقمي لقياس هذا

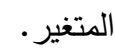

9ـ المشاركة الاجتماعية اللارسمية للمبحوث: يُقصد بها

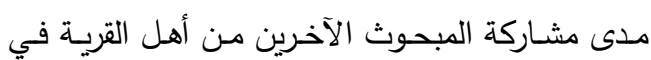

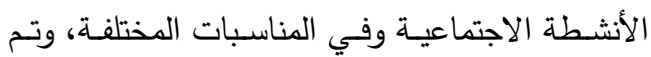

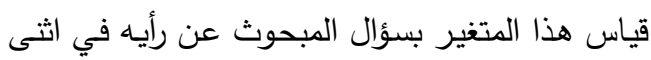

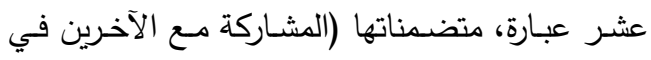

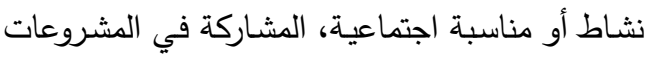

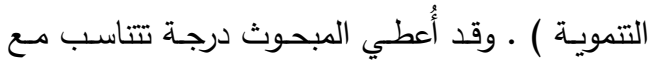

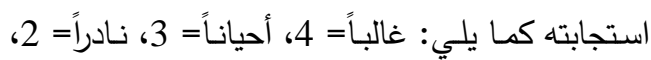
لا=1، واستُخدم مجموع الدرجات التي تحصل عليها المبحوث كمؤشر رقمي لقياس هذا المتغير.

10- مشاركة المبحوث في المشروعات التتموية: تم قياس كئس

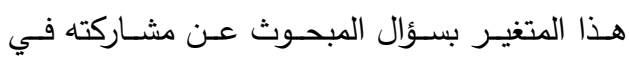
المشـروعات التتمويـة التـي تم إنجازهـا في القريـة. حيث أُعطى المبحوث درجة واحدة عن كل مشروع
أعطى المبحوث درجة تتتاسب مع درجة تعرضه لكل

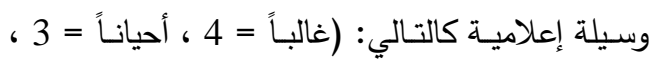
نادراً = 2 ، لا = 1 1)، وجُمعت الدرجات التي التي حصل عليها المبحوث واستخدت كمؤشر رقمي لقياس هذا

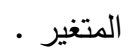
5- اســتخدام المبحــوث للإنترنـــت ومواقــع التواصـل الاجتمـاعي: يُعبر عـن معـدل اسـتخدام المبحـوث لثـبكة المعلومـات الدوليـة (الإنترنـتـات، وتطبيقاتهـا

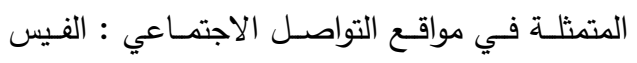

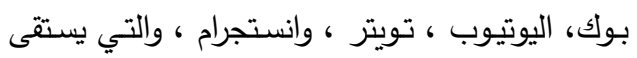

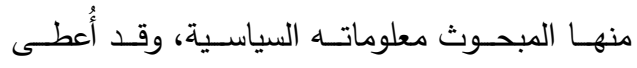
المبحوث درجـة تتناسب مـع معدل استخدامه لكل

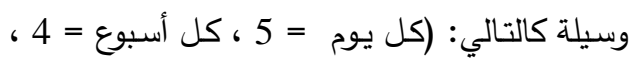

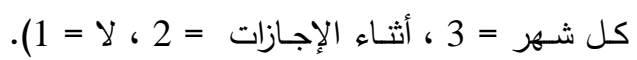

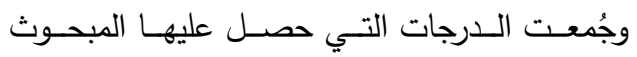
واستُخدمت كمؤشر رقمي لقياس هذا المتغير . 6- متابعـة المبحـوث للأخبار السياسية بوسـائل الإعـلام والإنترنت: يُعبر عن مدى اعتماد المبحوث على لئ

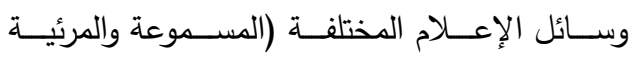

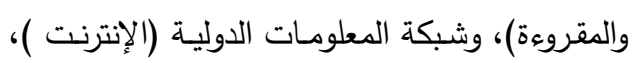

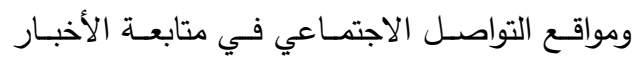

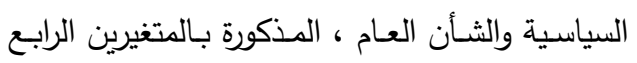

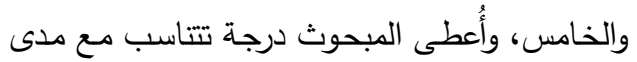

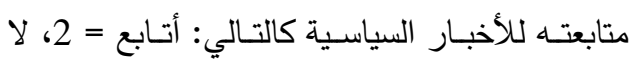

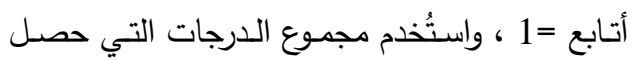
عليها المبحوث كمؤشر رقمي لقياس هذا المتغير . 7ـ الانفتاح الجغرافي للمبحـوث: يشير للحراك المكاني والذذي يعكس مـدى انفتـاح المبحـوث على العـالم

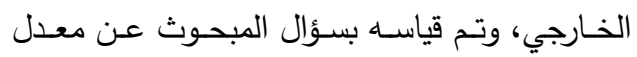

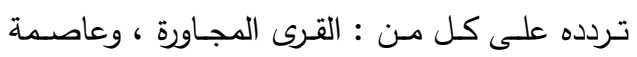

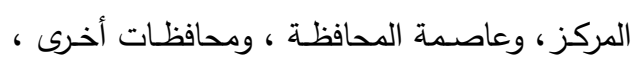

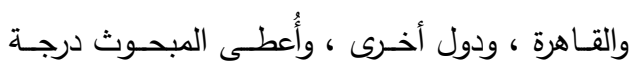

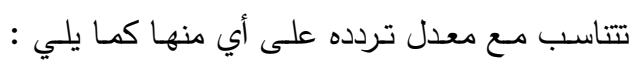

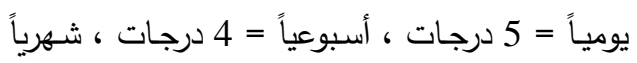


13ـ اتجاه المبحوث نحو المشـاركة التطوعية: يُقصد بـه درجة استجابة المبحوث للمشاركة التطوعية حيث تم قياس هذا المتغير بمعرفـة رأى المبحوث في أربعـة عبارات اتجاهية ، عبارتان منها إيجابية الاتجاه نحو المشاركة التطوعية تعكس ضرورة مشاركة الدولة في المشروعات التتموية ، وتواكل الافراد على الدولة في تتفيذ تلك المشروعات. وعبارتان سلبية الاتجاه نحو المشاركة وتعكس اعتماد الافراد على الدولة ، سلبية الافراد تجاه القرية ـ ودرجت اجابات المبحوثين علي مؤشر ثلاثي الأبعاد( موافق ، محايد، غير موافق)

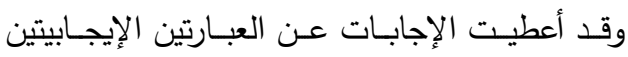

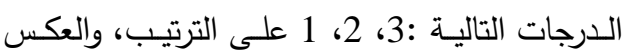
في حالـة العبـارات السـلبية، واستُخدم حاصـل جمـع الـدرجات التي حصـل عليهـا كل مبحـوث كمؤشـر رقمي لقياس هذا المتغير.

14ـ درجـة ثقـة المبحـوث في الأجهـزة الحكوميـة: يعكس

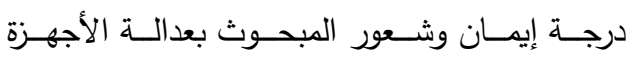
الحكوميــة واطمئنانـه لهـا ، وتـم قيـاس هذا لهـا المتغيـر باستطلاع رأى المبحوث في تسعة عبارات اتجاهية ، عبارتين منهج إيجابيتين وسبعة عبارات سلبية الاتجاه

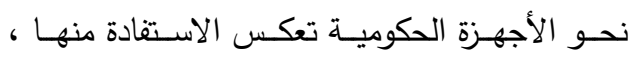

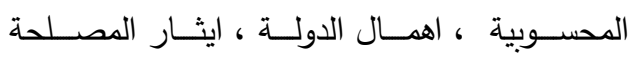

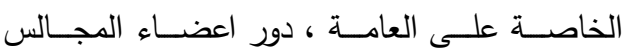
المحليـة. ودرجـت اجابـات المبحـوثين علـي مؤشـر ثلاثي الأبعـاد ( موافق ، محايد، غير موافق) وقد أعطيت الإجابات عن العبارتين الإيجابيتين الدرجات التالية :3، 2، 1 على الترتيب ، والعكس في حالـة العبـارات السلبية، واستُخدم حاصـل جمـع الـدرجات التي حصل عليها كل مبحوث كمؤشر رقمي لقياس

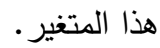

15ـ قيـادة الـرأي لـدي المبحـوث: يُقصـــ بـه درجـة إدراك المبحـوث لقدرتـه على التأثير في الآخـرين ومـدهم بالمعلومات والنصائح أو الاستشارات التي يحتاجونها

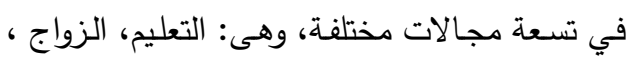

شـارك فيـه، وتضــاف درجـة تتناسـب مـع صــورة مشاركته بكل مشروع كما يلي: مالية=4، عينية =3،

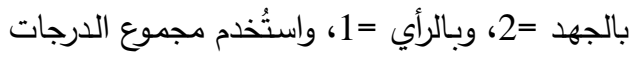
التي تحصل عليها المبحوث كمؤشر رقمي لقيـاس

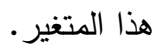
11ـ مشـاركة المبحـوث في المنظمـات الاجتماعيـة: تم قياسـاه بسؤال المبحوث عن مشـاركته في المنظمات الاجتماعيــة التاليــة: الجمعيــة التعاونيــة الزراعيــة، وجمعيـة تنميـة المجتــع، ومركز الشباب بالقريـة أو النادي، ومجلس الأمنـاء بالمدرسـة، والنقابـات أو أي لي

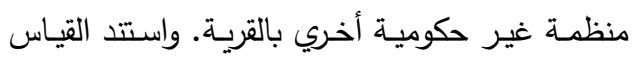

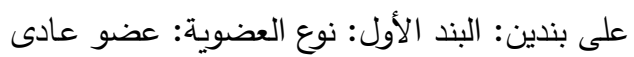

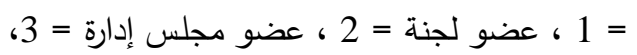
ورئسيس مجلـس إدارة = 4، والبنــد الثـاني: درجــة

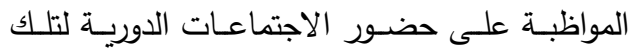

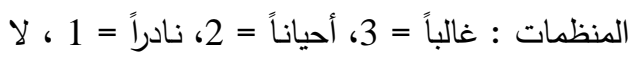
= صفر، وقد استُخدم مجموع الدرجات التي حصل عليها المبحوث في البندين كمؤشر رقمي لقياس هذا

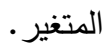

12. شعور المبحوث بالرضـا عن القريـة: يشير إلى درجة

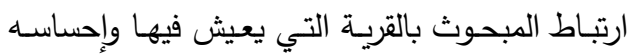

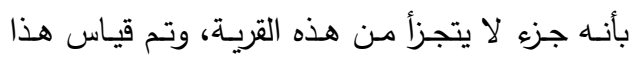

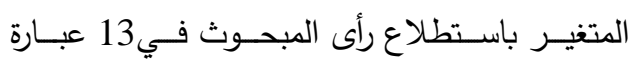
اتجاهيه، 8عبارات منها إيجابية الاتجاه ، و5عبارات

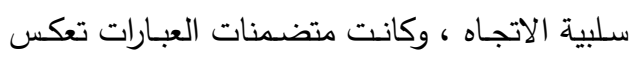

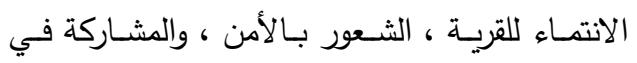

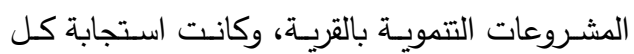
مبحوث عن كل عبارة بأحد الإجابات التالية : موافق

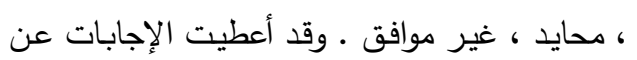
العبـارات الموجبـة الدرجات التاليـة: 3، 2، 1 على لـى الترتيب، بينما أُعطيت الإجابات عن العبارات السلبية الدرجات 1، 2، 3 على الترتيب. وتم جمع الدرجات التي حصل عليها كل مبحوث في جميع العبارات كمؤشر رقمي لقياس هذا المتغير . 
20- الحالـة الزواجيـة للمبحوث: وهى تُعبر عن الحالـة الزواجية التي يكون عليها المبحوث.

21- درجة المعرفة السياسية للشباب الريفي: تم قياس هذا

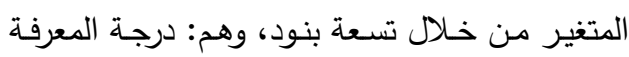
بالأحزاب السياسية، درجة معرفة اسم حزب الأكثرية بمجلس النواب، درجة معرفة أسماء المرشحين في

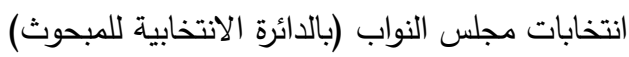
على المقاعد الفردية والقوائم، درجة معرفة اسم رئيس مجلس النواب والوكيلين، درجة معرفـة اسم رئيس الوزراء المصري الحالي، درجة معرفة عدد الوزراء

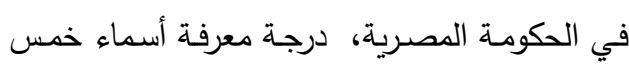

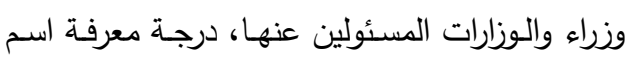

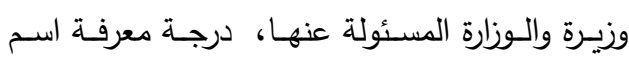

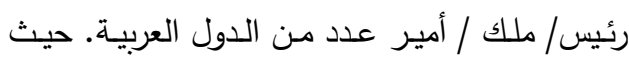

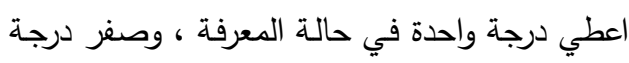

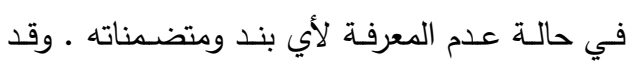

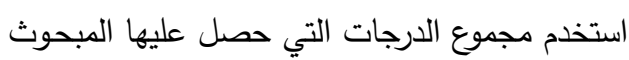
كمؤشر رقمي القياس هذا المتغير • والجدول رقم (1)

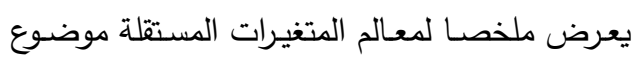
الدراسة.

المتغير التابع: درجة المشاركة السياسية للشباب الريفي: ويمثل المتغيـر التسابع الرئيسـي بهـذه الدراسـة، ولتحليـل البيانـات إحصـائياً تـم قيـاس متغيـر المشــاركة السياسـية للشباب باستخدام مؤشر مركب من ثلاثة متغيرات فرعية

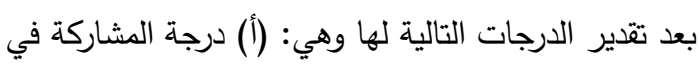

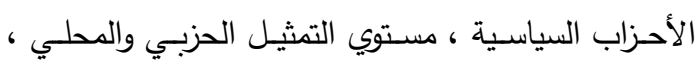

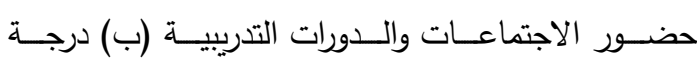
المشاركة بالتصويت في الانتخابات العامـة التي أجريت عامي( 2014 - 2015 ) (ج) درجـة المشاركة بالترشيح الأنيح في الانتخابـات (الاتحـادات الطلابيـة، والأنديـة ومراكـز الشباب، والنقابات والاتحادات العمالية، ومجلس النات النواب). وقد استخدم مجموع الدرجات التي حصل عليها المبحوث

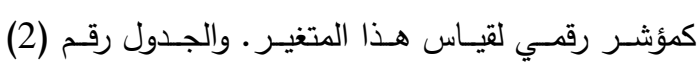

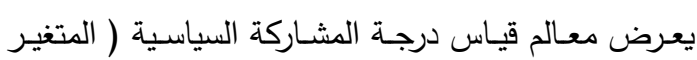
(التابع).
المصالحة وحل الخلافات بين الثباب، أمور خاصة

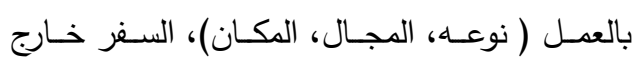

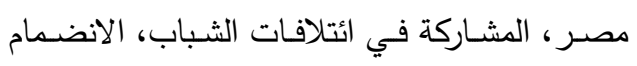

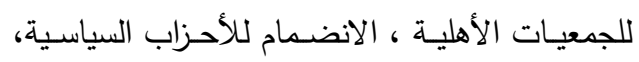

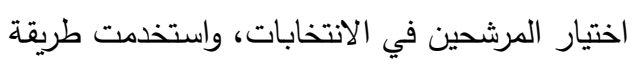

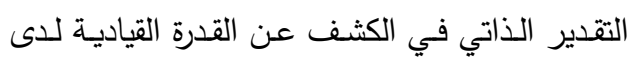

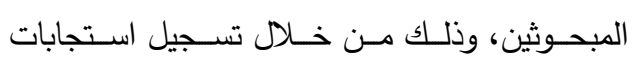

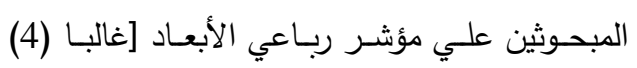

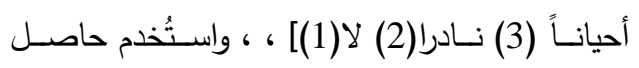

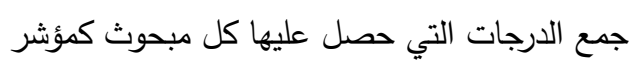
رقمي لقياس هذا المتغير. 16. حجم أسرة المبحوث: قيس كرقم مطلق يعبر عن عدد

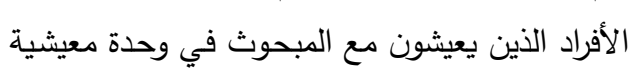
واحدة.

17 ـ مستوى تعليم أسرة المبحوث: تم قياسها بجمع عدد سنوات التعليم الرسمي التي أتمها كل فرد من أفراد أسـرة المبحـوث فـي سـن التعلـيم ( 6- 18 ســنة) وقسمتها على عدد هؤلاء الأفراد.

18- الوضـع الاجتمـاعي والاقتصــــي لأسـرة المبحـوث:

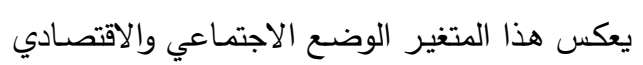

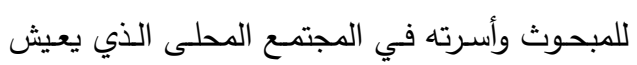
فيـه، واستُّد في قياسـه على ثلاثنة متغيرات فرعيـة وهي: متوسط الدخل الثهري للأسرة بالجنيـه كرقم

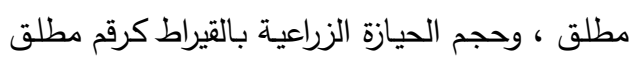

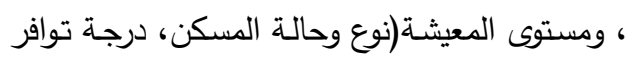

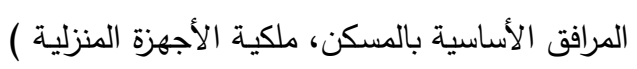

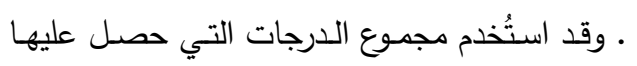

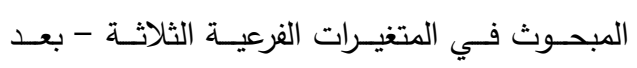
معايرتها وتحويلها إلى درجات تائية T-Scores كمؤشر رقمي لقياس هذا المتغير. 19- مهنة المبحوث: ويقصد بها مهنته الأساسية وهى المهنة التي يعمل بها ويعتمد عليها كمصدر أساسي ولئي

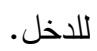


جدول ( 1 ) ): ملخص معالم المتغيرات المستقلة بعينة الدراسة

\begin{tabular}{|c|c|c|c|c|c|c|}
\hline \multicolumn{5}{|c|}{ 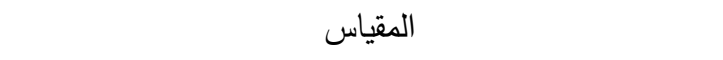 } & \multirow[b]{2}{*}{ المتغيرات المستقلة } & \multirow[b]{2}{*}{ r } \\
\hline 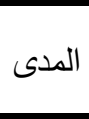 & قأكبر & قيمة & 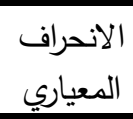 & الحستيط & & \\
\hline 14 & 35 & 21 & 4.398 & 27.24 & عمر المبحوث & 1 \\
\hline 12 & 18 & 6 & 2.227 & 12.88 & مستوى تعليم المبحوث & 2 \\
\hline 3000 & 3000 & 0 & 746.399 & 1132.00 & الدخل الشهري للمبحوث & 3 \\
\hline 19 & 28 & 7 & 3.088 & 12.12 & الانفتاح الثقافي للمبحوث & 4 \\
\hline 20 & 25 & 5 & 5.080 & 13.01 & الاجتماعي المبحوث للإنترنت ومواقع التواصل & 5 \\
\hline 6 & 20 & 10 & 1.360 & 10.94 & والإنترنت المبحوث للأخبار السياسية بوسائل الإعلام & 6 \\
\hline 26 & 28 & 2 & 5.900 & 9.70 & الانفتاح الجغرافي للمبحوث & 7 \\
\hline 42 & 66 & 22 & 9.777 & 47.74 & التتشئة الاجتماعية والسياسية للمبحوث & 8 \\
\hline 27 & 44 & 17 & 5.432 & 29.72 & المشاركة الاجتماعية اللارسمية للمبحوث & 9 \\
\hline 8 & 8 & 0 & 1.600 & 0.69 & مشاركة المبحوث في المشروعات التتموية & 10 \\
\hline 15 & 15 & 0 & 2.699 & 1.34 & مشاركة المبحوث في المنظمات الاجتماعية & 11 \\
\hline 19 & 37 & 18 & 3.031 & 29.09 & شعور المبحوث بالرضا عن القرية & 12 \\
\hline 4 & 12 & 8 & 1.578 & 8.46 & اتجاه المبحوث نحو المشاركة التطوعية & 13 \\
\hline 14 & 27 & 9 & 2.948 & 12.97 & درجة ثقة المبحوث في الأجهزة الحكومية & 14 \\
\hline 25 & 34 & 9 & 5.384 & 18.24 & قيادة الرأي لدي المبحوث & 15 \\
\hline 5 & 7 & 2 & 1.306 & 4.14 & حجم أسرة المبحوث & 16 \\
\hline 40 & 40 & 0 & 4.216 & 10.08 & مستوى تعليم أسرة المبحوث & 17 \\
\hline 145 & 280 & 135 & 23.530 & 199.98 & الوضع الاجتماعي والاقتصادي لأسرة المبحوث & 18 \\
\hline & ominal & riabl & 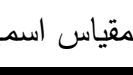 & & مهنة المبحوث & 19 \\
\hline & ominal & riabl & 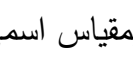 & & الحالة الزواجية للمبحوث & 20 \\
\hline 38 & 38 & صفر & 8.833 & 8.26 & درجة المعرفة السياسية للشباب الريفي & 21 \\
\hline
\end{tabular}


جدول (2): معالم قياس درجة المشاركة السياسية ( المتغير التابع).

\begin{tabular}{|c|c|c|c|c|c|c|}
\hline المدى & اكبر قيمة & اقل قيمة & 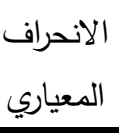 & الحسابي & \multicolumn{2}{|l|}{ 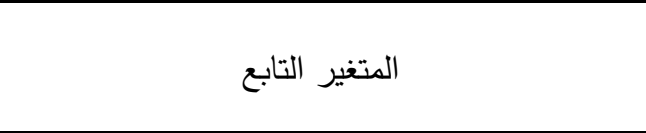 } \\
\hline 5 & 5 & 0 & 1.482 & 1.81 & \multicolumn{2}{|l|}{ 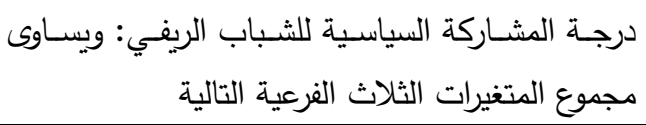 } \\
\hline 0 & 0 & 0 & 0 & 0 & درجة المشاركة في الأحزاب السياسية & 1 \\
\hline 3 & 3 & 0 & 1.372 & 1.66 & درجة المشاركة بالتصويت في الانتخابات & ب \\
\hline 2 & 2 & 0 & 0.442 & 0.14 & درجة المشاركة بالترشيح في الانتخابات & ج \\
\hline
\end{tabular}

المصدر : جمعت وحسبت من بيانات الدراسة الميدانية.

تقدير كل من المتوسطات الحسابية والانحرافات المعيارية

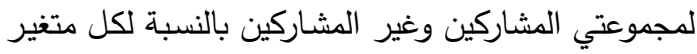

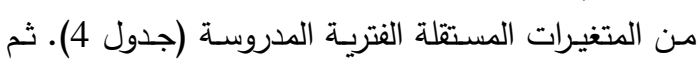

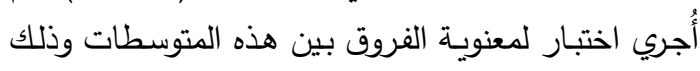

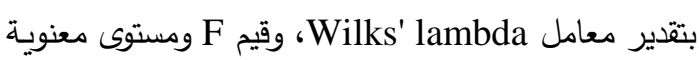

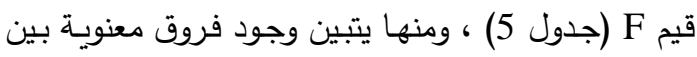

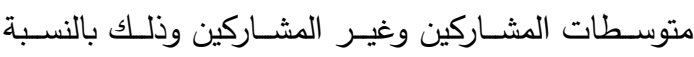

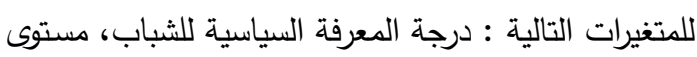

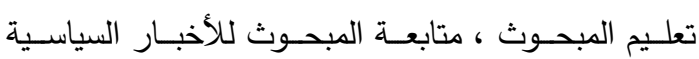

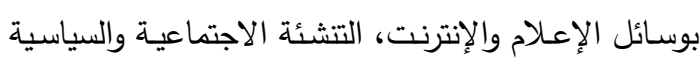

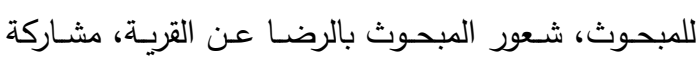
المبحوث في المنظمات الاجتماعية، ومستوى تعليم أسرة

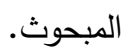

وباستعراض قيم معامل التمييز المعياري (SCDFC)

Standard Canonical Discriminant Function بهـف تحديد الإسهام النسبي من دالـة Coefficient

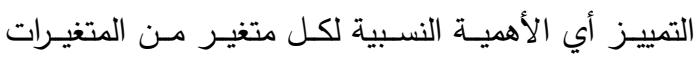

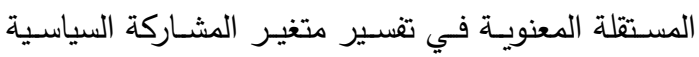

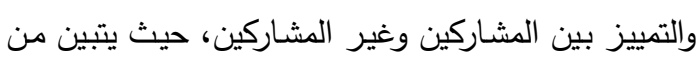

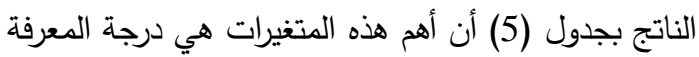

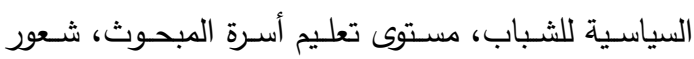

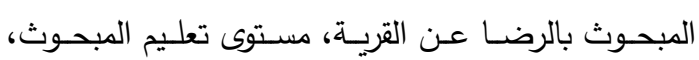

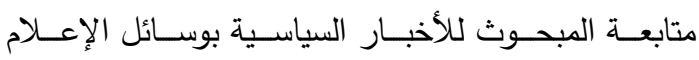

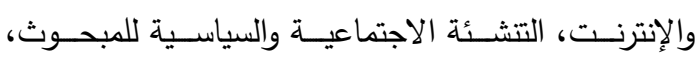
ومشاركة المبحوث في المنظمات الاجتماعية.

\section{النتائج ومناقثتها}

أولاً : مستوى المشاركة السياسية للثباب الريفي

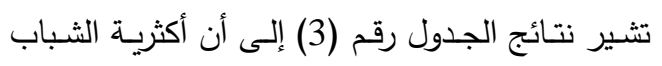

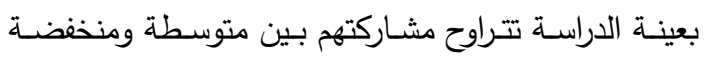

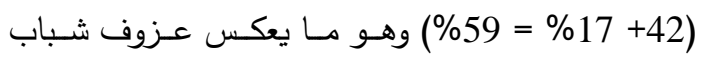

$$
\text { العينة عن المشاركة نسبيا. }
$$

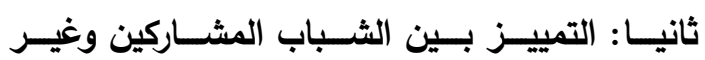
المشاركين سياسياً بعينة الدراسة:

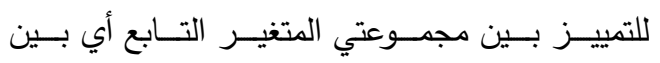

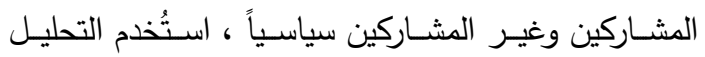

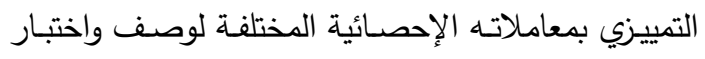

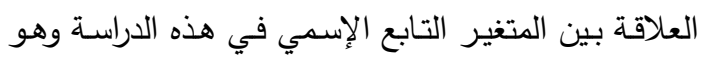

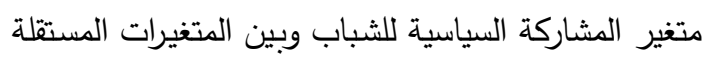

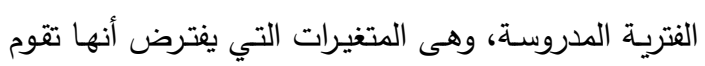

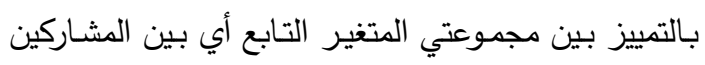

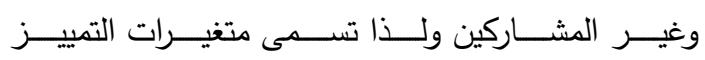
. Discriminating Variables

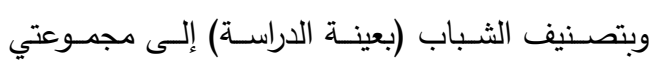
المتغير التابع يتضح أن عدد الشباب المشاركين بلغ 132

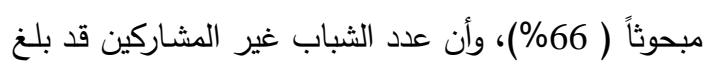
68 مبحوثاً (34\%). ولمعرفة المتغيرات المستقلة الفترية المدروسة التي تقوم

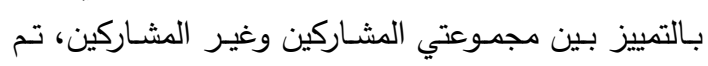


Canonical Correlation المجموعات ودالة التمييز الذي بلـخ 0.479. فدلالـة قيمة Eta2 تماثل R2 وكذلك قيمة ג تماثل 1-R2 في تحليل الاتحدار المتعدد (سلامة

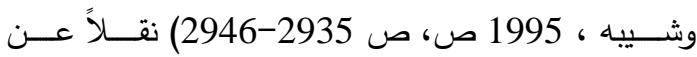
[Norusis and Kleccka] المستقلة المستخدمة في هذه الدراسة قد نجحت في تفسير

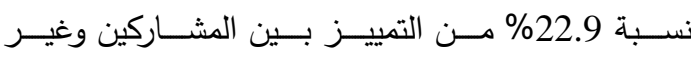
المشـاركين، بينمـا تمثل قيمـة ح والتـي تسـاوى 72.1 التمييز المتبقي والذى يعزى تفسيره إلى متغيرات أخرى

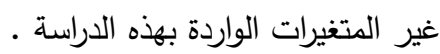

وتبين نتائج التصنيف (جدول 7) إلى أي مدى يمكن أن تساعد نتائج التحليل التمييزي في التتبؤ بسلوك الشباب التهاب نحو المشاركة السياسية ، حيث يتضح أن 101 مبحوث تتطبق عليهم خصـائص المشـاركين بنسبة 76.5\% ، و 31 مبحوث بنسبة 23.5\% لم تنطبق عليهم خصسائص

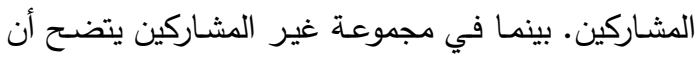
43 مبحوث بنسبة 63.2\% تنطبق عليهم خصائص غير المشاركين، و 25 مبحوث بنسبة 36.8\% لم تتطبق عليهم

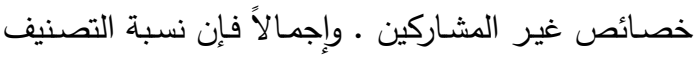

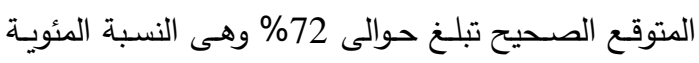

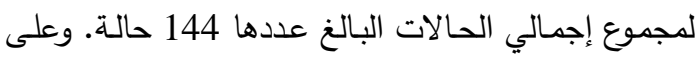

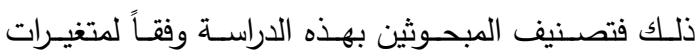
التمييز المستخدم يؤدى إلى توزيع صحيح بنسبة 72\%

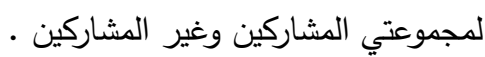

وبفحص قيم معاملـل الارتبـاط بين متغيـرات التمييز

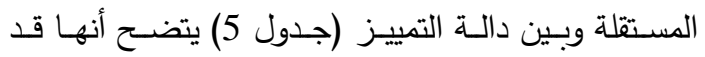
تراوحت بين حوالى 0.649 لمتغير درجة المعرفة السياسية

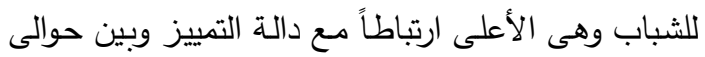

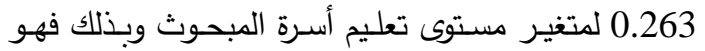

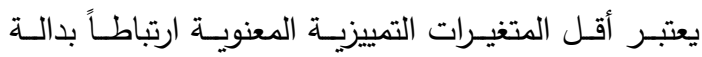
التمييز وللتعرف على مؤشرات دالة التمييز (جدول 6) والتى تساعد على التتبؤ بتأثير مجموعة المتغيرات المستقلة على دلى التيز المتغير التابع وهو متغيـر المشـاركة السياسية في هذئه الدراسة يتبين أن قيمة (X) Wilks' lambda للتمييز بين المشـاركين وغير المشـاركين قد بلغت 0.770 وأن قيمـة مربع كـاى بلغت 49.155 وهـى معنويـة على المستوى الاحتمـالي 0.01 ممـا يـل على بلى جوهريـة معامل $\lambda$ وهذا يثـير إلى معنويـة فروق المتغيـرات المستقلة المستخدمة للتمييز بين المشاركين وغير المشاركين. وينبني الإثـارة إلى أنه كلما قلت قيمة (X) Wilks' lambda عن 0.5 أو اقتربت قيمتها من الصفر كلما دل على الاختلاف التام بين متوسطات مجموعتي المتغير التابع أي بين المشاركين الأني

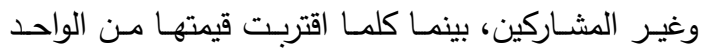
الصحيح كلما دل على تقارب متوسطات المجموعتين. ويتضـح أيضـاً من النتائج بجدول (6) أن قيمة Eta2 والتي تساوى حاصل ضرب 'Eigenvalue x Wilks lambda

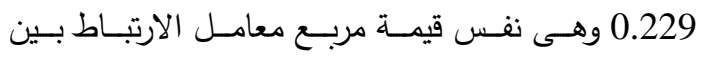

جدول (3): توزيع الثباب بعينة الدراسة وفقاً للارجة الكلية للمشاركة السياسية

\begin{tabular}{|c|c|c|}
\hline$\%$ & عدد المبحوثين & فئات درجة المشاركة السياسية \\
\hline 34.0 & 68 & ل ل ل يشارك \\
\hline 17 & 34 & منخفض (1 - 2 درجة) \\
\hline 42 & 84 & متوسط ( 3 درجات) \\
\hline 7 & 14 & مرتفع ( 4- 5 درجات) \\
\hline 100 & 200 & المجموع \\
\hline
\end{tabular}


F.S. Salama, et al.,

جدول (4): المتوسط الحسابي والانحراف المعياري لمتغيرات التمييز لكل من المشاركين وغير المشاركين من الثباب بعينة

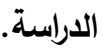

\begin{tabular}{|c|c|c|c|c|c|c|c|}
\hline \multicolumn{3}{|c|}{ الانحراف المعياري } & \multicolumn{3}{|c|}{ المتوسط الحسابي } & \multirow[b]{2}{*}{ المتغيرات } & \multirow[b]{2}{*}{ r } \\
\hline كل العينة & المشاركين & المشاركين & كل العينة & المشاركين & المشاركين & & \\
\hline 4.398 & 4.311 & 4.444 & 27.24 & 26.84 & 27.45 & عمر المبحوث & 1 \\
\hline 2.227 & 2.206 & 2.185 & 12.88 & 12.29 & 13.18 & مستوى تعليم المبحوث & 2 \\
\hline 746.399 & 682.470 & 777.560 & 1132.00 & 1065.44 & 1166.29 & الدخل الثهري للمبحوث & 3 \\
\hline 3.088 & 2.542 & 3.304 & 12.12 & 11.54 & 12.42 & الانفتاح الثقافي للمبحوث & 4 \\
\hline 5.080 & 4.319 & 5.435 & 13.01 & 12.62 & 13.21 & ومواقع التواصل الاجتماعل للإنترنت & 5 \\
\hline 1.360 & 1.095 & 1.453 & 10.94 & 10.60 & 11.11 & السياسية بوسائل الإعلام & 6 \\
\hline 5.900 & 5.655 & 6.044 & 9.70 & 9.75 & 9.68 & الانفتاح الجغرافي للمبحوث & 7 \\
\hline 9.777 & 9.736 & 9.616 & 47.74 & 45.41 & 48.94 & التتشئة الاجتماعية والسياسية & 8 \\
\hline 5.432 & 5.695 & 5.314 & 29.72 & 29.66 & 29.74 & المشاركة الاجتماعية اللارسمية & 9 \\
\hline 1.600 & 1.469 & 1.665 & 68. & 0.57 & 0.74 & مشاركة المبحوث في & 10 \\
\hline 2.699 & 1.668 & 3.068 & 1.34 & 0.81 & 1.62 & مشاركة المبحوث في المنظمات & 11 \\
\hline 3.031 & 2.563 & 3.197 & 29.09 & 28.40 & 29.45 & شعور المبحوث بالرضا عن & 12 \\
\hline 1.578 & 1.488 & 1.628 & 8.46 & 8.40 & 8.50 & الجاه المبحوث نحو المشاركة & 13 \\
\hline 2.948 & 2.828 & 3.016 & 12.97 & 12.82 & 13.05 & درجة ثقة المبحوث في الأجهزة & 14 \\
\hline 5.384 & 5.585 & 5.272 & 18.24 & 17.63 & 18.56 & قيادة الرأي لدي المبحوث & 15 \\
\hline 1.306 & 1.309 & 1.298 & 4.14 & 4.32 & 4.04 & حجم أسرة المبحوث & 16 \\
\hline 4.216 & 5.039 & 3.670 & 10.08 & 10.91 & 9.65 & مستوى تعليم أسرة المبحوث & 17 \\
\hline 23.530 & 26.504 & 21.852 & 199.98 & 197.64 & 201.19 & الوضع الاجتماعي والاقتصادي & 18 \\
\hline 0.353 & 0.465 & 0.240 & 0.86 & 0.69 & 0.94 & درجة المعرفة السياسية للشباب & 19 \\
\hline
\end{tabular}

المصدر : حسبت من بيانات الدراسة الميدانية باستخدام الحاسب الآلي . 
جدول (5): معامل Wilks' lambda ومستوى المعنوية ومعامل التمييز المعيارى (SCDFC) ومعامل الارتباط بين متغيرات التمييز ودالة التمييز لعينة الثباب.

\begin{tabular}{|c|c|c|c|c|c|c|}
\hline الارتباط & SCDFC & المعنوية & F & $\begin{array}{l}\text { Wilks' } \\
\text { lambda }\end{array}$ & 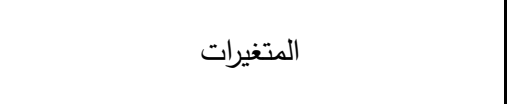 & r \\
\hline 0.121 & $0.185-$ & 0.355 & 0.859 & 0.996 & عمر المبحوث & 1 \\
\hline 0.353 & 0.400 & 0.007 & 7.357 & 0.964 & مستوى تعليم المبحوث & 2 \\
\hline 0.118 & $0.037-$ & 0.367 & 0.819 & 0.996 & الدخل الثهري للمبحوث & 3 \\
\hline 0.250 & 0.226 & 0.056 & 3.695 & 0.982 & الانفتاح الثقافي للمبحوث & 4 \\
\hline 0.102 & $0.318-$ & 0.434 & 0.613 & 0.997 & استخدام المبحوث للإنترنت ومواقع التواصل & 5 \\
\hline 0.327 & 0.166 & 0.013 & 6.304 & 0.969 & $\begin{array}{c}\text { متابعة المبحوث للأخبار السياسية بوسائل } \\
\text { الإعلام والإنترنت }\end{array}$ & 6 \\
\hline $0.010^{-}$ & 0.139 & 0.939 & 0.006 & 1.000 & الانفتاح الجغرافي للمبحوث & 7 \\
\hline 0.319 & 0.116 & 0.015 & 5.989 & 0.971 & التتئئة الاجتماعية والسياسية للمبحوث & 8 \\
\hline 0.013 & 0.046 & 0.921 & 0.010 & 1.000 & المشاركة الاجتماعية اللارسمية للمبحوث & 9 \\
\hline 0.092 & $0.036-$ & 0.481 & 0.499 & 0.997 & مشاركة المبحوث في المشروعات التتموية & 10 \\
\hline 0.265 & 0.065 & 0.043 & 4.131 & 0.980 & مشاركة المبحوث في المنظمات الاجتماعية & 11 \\
\hline 0.306 & 0.490 & 0.020 & 5.506 & 0.973 & شعور المبحوث بالرضا عن القرية & 12 \\
\hline 0.057 & $0.104-$ & 0.663 & 0.190 & 0.999 & اتجاه المبحوث نحو المشاركة التطوعية & 13 \\
\hline 0.066 & 0.100 & 0.615 & 0.253 & 0.999 & درجة ثقة المبحوث في الأجهزة الحكومية & 14 \\
\hline 0.151 & $0.158-$ & 0.249 & 1.336 & 0.993 & قيادة الرأي لدي المبحوث & 15 \\
\hline $0.191-$ & $0.371^{-}$ & 0.143 & 2.160 & 0.989 & حجم أسرة المبحوث & 16 \\
\hline $0.263^{-}$ & $0.491^{-}$ & 0.045 & 4.073 & 0.980 & مستوى تعليم أسرة المبحوث & 17 \\
\hline 0.132 & 0.167 & 0.314 & 1.020 & 0.995 & الوضع الاجتماعي والاقتصادي لأسرة المبحوث & 18 \\
\hline 0.649 & 0.628 & 0.000 & 24.853 & 0.888 & درجة المعرفة السياسية للشباب & 19 \\
\hline
\end{tabular}

المصدر : حسبت من بيانات الدراسة الميدانية باستخدام الحاسب الآلي . 
F.S. Salama, et al.,

جدول (6): مؤشرات دالة التمييز الخاصة بالثباب بعينة الدراسة.

\begin{tabular}{|c|c|c|c|}
\hline Canonical corr. ** & النسبة المتجمعة & نسبة التباين & Eigenvalues \\
\hline 0.479 & 100.00 & 100.00 & 0.298 \\
\hline درجات الحرية & مربع كاي & $\mathrm{Eta}^{2}$ & Wilks' lambda \\
\hline 19 & $* * * 49.155$ & 0.229 & 0.770 \\
\hline \multicolumn{3}{|c|}{0.000 *** مستوى معنوية } & ي معنوية 0.01 \\
\hline
\end{tabular}

جدول (7): نتائج التصنيف الفعلي والمتوقع للمشاركين وغير المشاركين من الثباب بعينة الدراسة.

\begin{tabular}{|c|c|c|c|}
\hline \multicolumn{2}{|c|}{ التصنيف المتوقع } & \multicolumn{2}{|c|}{ التصنيف الفعلي } \\
\hline غير المشاركين & المشاركون & العدد العد & المجموعة \\
\hline$(\% 23.5) 31$ & (\%76.5)101 & 132 & المشاركون \\
\hline$(\% 63.2) 43$ & (\%36.8)25 & 68 & غير المشاركين \\
\hline
\end{tabular}

المصدر : حسبت من بيانات الدراسة الميدانية باستخدام الحاسب الآلي .

المبحوث في المنظمات الاجتماعية، ومستوى تعليم أسرة

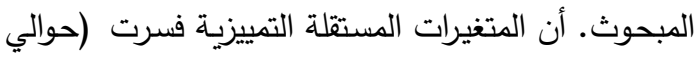
23\%) مـن التمييـز بـين المشـاركين وغيـر المشـاركين سياسياً.

وبناءً على ما توصلت إليه الدراسة من نتائج، توصي

$$
\text { الدراسة بما يلي-: }
$$

1- الاهتمام من قبل الدولة بمؤسساتها المختلفة وخاصـة

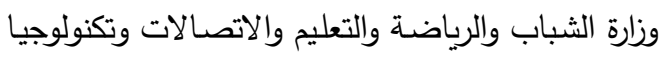

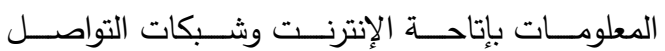
الاجتماعي - بصفة عامة وقبل الاستحقاقات الانتخابية

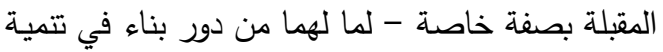

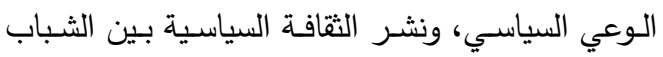

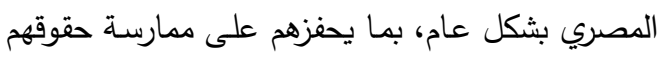
السياسية والمشاركة المجتمعية الفاعلة.
وبناءً علي تلك النتائج يمكن رفض الفرض الإحصائي المتعلق بالفرض النظري الثالث بالنسبة للمتغيرات المستقلة - سـالفة الذكر - والتي ثبت قدئ قدرتها علـي التمييز بـين

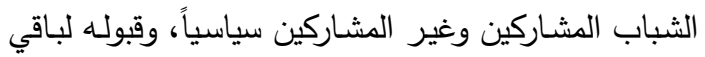

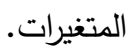

\section{الخلاصة والتوصيات}

تشير نتائج التحليل الإحصائي للبيانات المتعلقة بـالمبحوثين الي أن أكثريـة الثباب (42\% منهم ) كانت مشاركتهم السياسية متوسطة إلي منخفضة. مساهمة سبع متغيـرات في التمييز بـين المشـاركين وغيـر المشـاركين

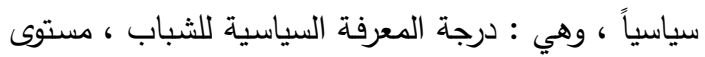
تعليم المبحـوث ، متابعـة المبحـوث للأخبـار السياسـية بوسائل الإعلام والإنترنت، التتشئة الاجتماعية والسياسية للمبحـوث، شـعور المبحوث بالرضـا عن القريـة، مشـاركة 
الإمـام ، محمد السيد ، مصـطفى البنـاري (2010) دور

الاتصـال الجماهيري في تتمية وعى الشباب بالتتمية:

دراسة ميدانية في احدى قرى محافظة الدقهلية ، مجلة

جامعة المنصورة ، مجلد (1)، عدد (6) .

الجريدة الرسمية المصرية (2014) قانون مجلس النواب،

العدد 23 (تابع)، بتاريخ 5 / 6 / 2014.

الجوهري، أبى نصر إسماعيل بن حماد (2009) الصحاح

تاج اللغة وصحاح العربية، مجلد (1) ، دار الحديث ،

$$
\text { القاهرة . }
$$

الجوهري، عبد الهادي (1985) دراسات في علم الاجتماع

السياسي، مكتبة نهضة الثرق، مصر .

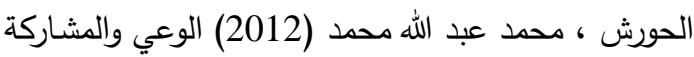

السياسية لدى المواطن اليمني: دراسـة ميدانية دراسـة

حالة لأمانة العاصمة صنعاء ، رسالة ماجستير ، كلية

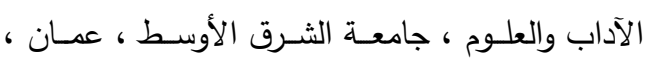

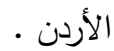

الدستور المصري 2014.

الاسـوقي ، مجدى محمد (2003) سيكولوجية النمو من الن

الميلاد إلى المراهقة ، الطبعة الأولى ، مكتبة الأنجلو

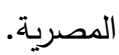

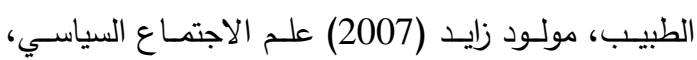

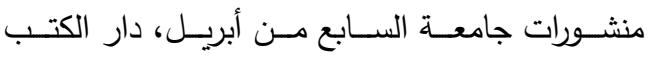

$$
\text { الوطنية، بنى غازي، ليبيا. }
$$

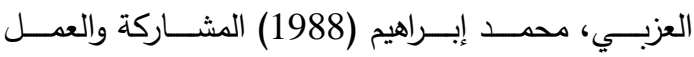

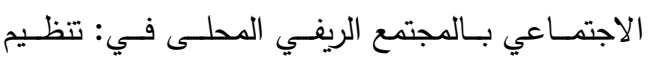

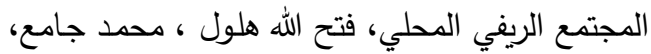

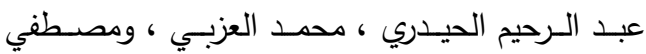

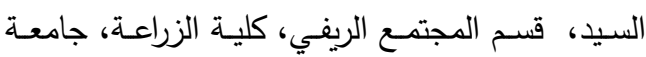

$$
\text { الإسكندرية. }
$$

النبي، حـاتم يوسـف محمـود عبدالغفار (2013) مقيساس

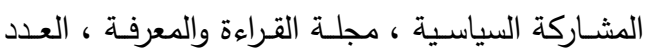

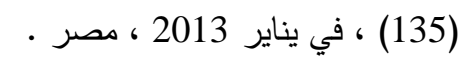

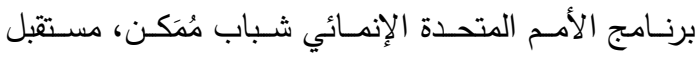

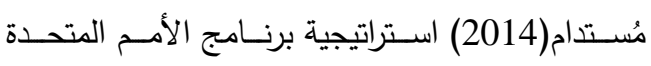

2- أن تقوم وزارة التربيـة والتعليم والتعليم العـالي والهيئة

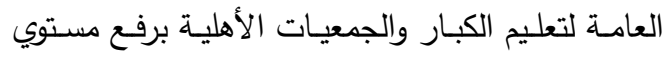
التعليم بالمناطق الريفية.

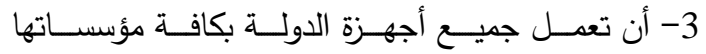

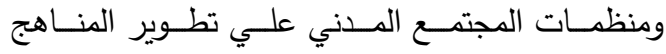

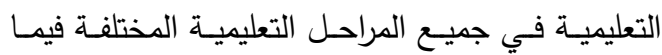

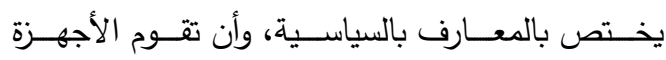
الإعلامية التقليدية بتطوير المحتوى الذي تقدمه البرامج

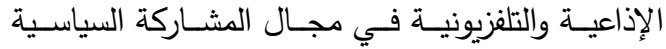

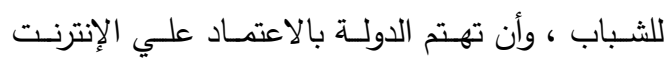

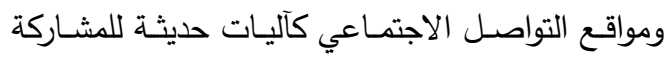
السياسية للشباب.

4- قيام وزارتي التضامن الاجتماعي والثباب والرياضـة ،

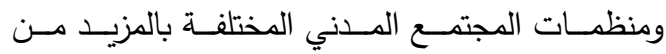

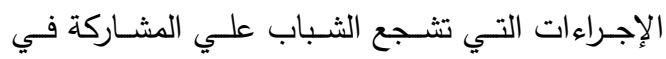

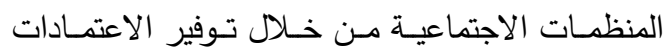

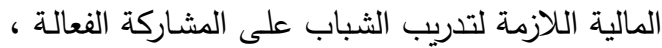

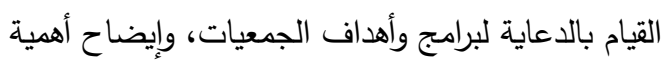

$$
\text { ودور الثباب في إنجاح هذه البرامج. }
$$

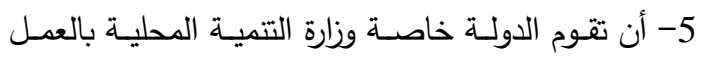

علي تقديم المزيد من الخدمات الأساسية التي تحتاجها لأنها المناطق الريفية

6- تـعيم جهود البـاحثين لإجراء المزيــــــن الدراسـات

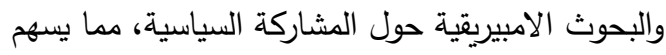
في فهم جوانبها المختلفة، ومـن ثم وضـع استراتيجية عامة لتفعيل المشاركة السياسية داخل المجتمع لجميع

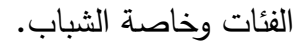

أبو حسين، ابتهال محمد كمال (2005) تحليل اجتماعي

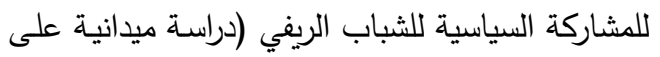
عينــة مـن الثــباب الريفـي بإحــى قـرى محافظــة

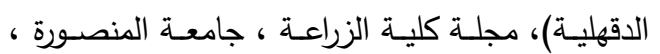

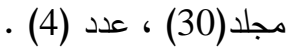




\section{F.S. Salama, et al.,}

شقير ، حفيظة (2004) دليل المشاركة السياسية للنساء

العربيات، المعهد العربي لحقوق الإنسان، تونس.

شقير، سيدريك (2013) الإدماج الاجتماعي والديمقراطية

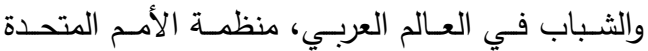
للتربية والعلم والثقافة، بيروت، لبنان.

عبد الحميد ، مجدى (غيـر مبـين التـاريخ ) المشـاركة والديمقراطية ، الجمعيـة الدصرية للنهوض بالمشاركة النية

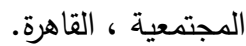
علام، صـلاح الدين محمود (1985) تحليل البيانات في البحوث النفسية والتزبوية، دار الفكر العربي، القاهرة. على، ناصـر محمود شيد شيخ (2008) دور منظمـات

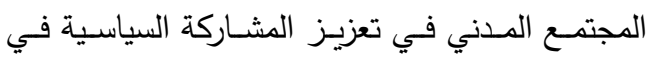
فلسطين ، رسالة ماجستير ، جامعة النجاح الوطنية ، نابلس ، فلسطين. علي، زغلول عباس حسنين (2009) تقويم دور جماعات

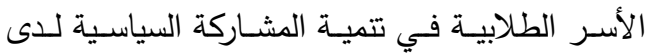
الثباب الجامعي: دراسة ميدانية مقارنة، مجلة دراسات في الخدمة الاجتماعيـة والعلوم الإنسانية، مجلد (2)، عدد (26)، مصر . قنديل ، أبو الفتوح عبد الحميد (2003) المشركة (لماركة السياسية

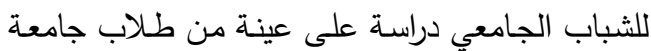

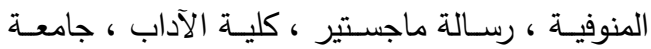

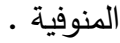

لمين ، لعجال أعجال محمد (2007) إثكالية المشاركة السياسية وثقافة السلم ، مجلة العلوم الإنسانية، جامعة محمد خيضر بسكرة ، عدد(12) ، الجزائر. ليلة، على (1993) الثباب العربي: تأملات في ظواهر الإحياء الديني والعنف، دار المعارف، الطبعة الثانية،

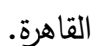
ليلة، على (2012) تحولات الرفض الثبابي: تأملات في

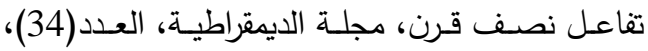
بتاريخ 2012/4/18. متـولي، عمـرو فـوزي طـهـ (2012) الثـباب والمشـاركة السياسية في مصر ، المجلة العلمية للدراسات التجارية
الإنهـائي للمســاواة بـين الجنسـين 2014 - 2017 ، برنامج الأمم المتحدة 2014 ، الإن

برو، فيليب (1998) علم الاجتمـاع السياسـي ، ترجمـة:

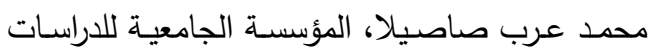
والنشر والتوزيع ، بيروت، لبنان .

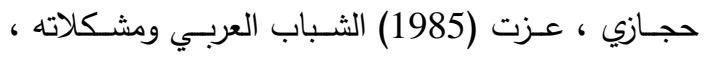

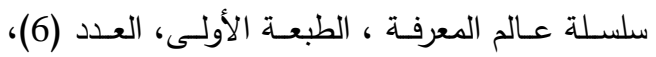
المجلس الوطني للثقافة والفنون والآداب ، الكويت . حجـازي، مصـطفي (2006) الإنسـان المهـدور دراســة

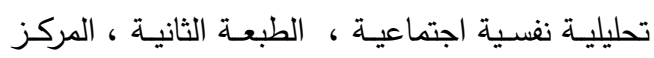
الثقافي العربي ، الدار البيضاء ، المغرب. حريزي ، زكرياء (2011)المشاركة السياسية للمرأة العربية ، الكغربة ودورهـا في تكريس في محاولـة تكريس الديمقراطيـة التشـاركية: الجزائر نموذجـا ، رسـالة ماجستير ، كليـة

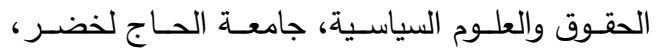

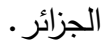

حندوسـة، هبـة (2010) تقرير التميـة البشرية في مصر عام 2010 ، معهة التخطيط القومي ، مصر .

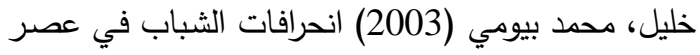
العولمة ، دار قباء للطباعة والنشر ، القاهرة.

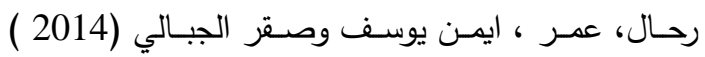

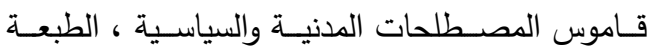
الأولـى ، مركـز إعـلام حقـوق الإنسـان ( شـمس)، فلسطين.

زهران، حامد عبد السلام (1972) علم نفس النمو، الطبعة الثانية ، عالم الكتب، القاهرة. سرحان، محد محمود محمد (2008) تفعيل دور مكاتب شباب المستقبل في تتمية الوعي السياسي لدى الثباب:

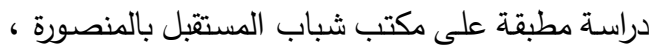

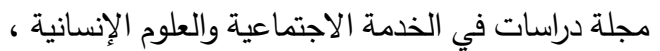
مجلد (3)، عدد(25). سلامة، فؤاد عبد اللطيف، محمد مصطفى شيبة (1995) التحليل التمييزي للمشاركة المحلية في قرية سعودية، مجلة جامعة المنصورة للعلوم الزراعية، كلية الزراعة . جامعة المنصورة ، مجلد (20) ، العدد (6). 
حسنين، محمد عبده (2015) انخفاض نسبة المشاركة

في الانتخابات البرلمانية يعمق حالة العزوف السياسي

لدى المصـريين، جريـدة الثـرق الأوسط ، العـدد رقم

$$
13475 \text { ، بتاريخ، 20/30 / 2015، في : }
$$

https://aawsat.com(25/9/2017- 7.30 Pm)

شـاهين، سوسـن(2010) دراسـة حـول مفهـوم المشـاركة

$$
\text { السياسية في فلسطين، في: }
$$

(18/ 2/2015 - $8.30 \quad$ Pm)

http://www.alankabout.com/feed/articles/31 922.txt

عثــان، ماجد (2015) البيـان الصـحفي حول استطلاع

مـا بعـد التصـويت في المرحلـة الثانيـة للانتخابـات

$$
\text { البرلمانية الذي أجراه مركز بصيرة، في: }
$$

http://www.baseera.com.eg (25/9/2017- 6.00 Pm)

عضيبات ، عاطف (2009) البروز الثبابي في المنطقة العربية: الأوضاع والتبعات السياسية ، في:

(9/ 12/2016 - $4.00 \quad$ Pm)

http://www.google.com/url?sa=t\&rct=ja.pdf http://himayashabab.blogspot.com.eg/2011/05/ blog-post_17.htm(18//2016 - 5.30 Pm)

file://E:/blog-post_18.html( 23/4/2016-3.30 Pm)

http://www.rdflwomen.org(1/9/2017-5.30 Pm)
والبيئية ، مجلد(3)، عدد(1) ، كلية التجارة ، جامعـة قناة السويس.

محمد ، فرحات عبد السيد ( 2011) محددات المشـاركة

السياسـية للشباب الريفـي: دراسـة مقارنـة بـين الذكور

والإنـاث بمحافظــة المنوفيـة ، مجلـة اتحـاد الجامعـات

العربية للعلوم الزراعية ، مجلد (19) ، العدد (1) •

ملحم ، سامى محمد (2004) علم نفس النمو: دورة حياة الإنسان ، الطبعة الأولى، دار الفكر، الأردن.

ميخائيل ، إيناس أسعد رزق (1999) الأسس الاجتماعية لتطوير أدوار الشباب الريفي في التنميـة ببعض قري محافظة الدقهليـة ، رسـالة ماجستير ، كليـة الزراعـة ، جامعة المنصورة .

واطسـون ، روبـرت ، هنـري كـلاي لينـدجرين (2004 ) سيكولوجية الطفل والمراهق ، ترجمة داليا عزت مؤمن، الطبعة الأولى ، مكتبة مدبولي ، القاهرة .

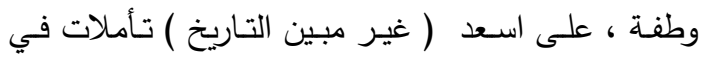
مفهومي الشباب وثقافة الشباب ، كلية التربية، جامعة الكويت . ب الكيتي تاج الدين، احمد سعيد(2014) من الموسوعة السياسية، في: http://www.sis.gov.eg/Ar/Default.aspx(11/2/ 2016- 5.00 Pm) 


\title{
ADSCRIMINANT ANALYSIS OF THE POLITICAL PARTICIPATION OF RURAL YOUTH IN MENOUFIA GOVERNORATE
}

\author{
F.S. Salama, F. A. Mohamed, Kh.A. Keneber and M.A. Younes
}

Department of Agricultural Extension and Rural Sociology, Faculty of Agriculture, Menoufiya University

\begin{abstract}
The main objective of this study was to identify and analyze the political participation of the rural youth. Data were collected from a random sample of 200 youth, in two villages at Menoufiya governorate through personal interviews with respondents. Data were analyzed descriptively and analytically by using frequencies, percentages, range, mean, variance, reliability estimate and the discriminant analysis technique was used to compare between participant youth and nonparticipant youth considering discriminating variables that included in this study.

Regarding the political participation of the rural youth, the results indicate:

(a) The majority of rural youth (42\%) had a medium to low level of political participation.

(d)The most important discriminating variables between participant youth and nonparticipant youth were political knowledge, youth education level, youth follow-up to political news in the media and Internet, social and political socialization of youth, youth' community satisfaction, youth participation in social organizations, family education level. These seven significant independent variables explained about $23 \%$ of the discrimination between participants and nonparticipants politically.
\end{abstract}

Key words: Rural Youth, Political Participation

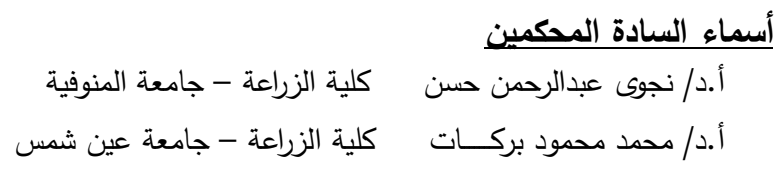

